\title{
Medicare Expenditures, Social Security Reform, and the Labor Force Participation of Older Americans
}

\author{
Yuanyuan Deng and Hugo Benítez-Silva
}

Project \#: R-UM15-13 


\title{
Medicare Expenditures, Social Security Reform, and the Labor Force Participation of Older Americans
}

\author{
Yuanyuan Deng \\ SUNY-Stony Brook
}

Hugo Benítez-Silva

SUNY-Stony Brook

September 2015

\author{
Michigan Retirement Research Center \\ University of Michigan \\ P.O. Box 1248 \\ Ann Arbor, MI 48104 \\ www.mrrc.isr.umich.edu \\ (734) 615-0422
}

\section{Acknowledgements}

The research reported herein was performed pursuant to a grant from the U.S. Social Security Administration (SSA) funded as part of the Retirement Research Consortium through the University of Michigan Retirement Research Center (5 RRC08098401-07). The opinions and conclusions expressed are solely those of the author(s) and do not represent the opinions or policy of SSA or any agency of the Federal Government. Neither the United States Government nor any agency thereof, nor any of their employees, makes any warranty, express or implied, or assumes any legal liability or responsibility for the accuracy, completeness, or usefulness of the contents of this report. Reference herein to any specific commercial product, process or service by trade name, trademark, manufacturer, or otherwise does not necessarily constitute or imply endorsement, recommendation or favoring by the United States Government or any agency thereof.

\section{Regents of the University of Michigan}

Michael J. Behm, Grand Blanc; Mark J. Bernstein, Ann Arbor; Laurence B. Deitch, Bloomfield Hills; Shauna Ryder Diggs, Grosse Pointe; Denise Ilitch, Bingham Farms; Andrea Fischer Newman, Ann Arbor; Andrew C. Richner, Grosse Pointe Park; Katherine E. White, Ann Arbor; Mark S. Schlissel, ex officio 


\title{
Medicare Expenditures, Social Security Reform, and the Labor Force Participation of Older Americans
}

\begin{abstract}
The changes to the Social Security Old Age benefits system introduced in the last decade, which will continue later this decade, have impacted individuals' labor supply and retirement decisions, and therefore their health insurance coverage. This paper provides an empirical analysis of the effects of the changes in the OA system, resulting from the 1983 Amendments, on Medicare costs. Using data from the Medicare Current Beneficiary Survey (MCBS), we empirically analyze the Medicare expenditures of individuals around retirement age as a function of their health insurance coverage and labor market attachment. Our results show a significant effect of employment measures as well as insurance coverage types, suggesting a sizable effect of employment and insurance on Medicare expenditures as well as on total health expenditures and on out-of-pocket health expenditures. Our findings allow us to compute the total savings to the Medicare system resulting from individuals' working while receiving health insurance coverage at older ages, and we estimate savings of 2.89 billion dollars a year, as well as another 333.67 million per year resulting from the delayed in enrollment into the Medicare system, given that some individuals do not enrolled in Medicare when first available, and this is more common among those who work and have insurance coverage. These results suggest that any future reform to the social insurance system will have to account for the effect on Medicare costs of policies that likely lead to increases in employment and employer provided health insurance coverage among populations eligible for Medicare.
\end{abstract}

\section{Citation}

Deng, Yuanyuan, and Hugo Benítez-Silva. 2015 “Medicare Expenditures, Social Security Reform, and the Labor Force Participation of Older Americans.” Ann Arbor, MI. University of Michigan Retirement Research Center (MRRC) Working Paper, WP 2015-330. http://www.mrrc.isr.umich.edu/publications/papers/pdf/wp330.pdf

\section{Authors' acknowledgements}

This work is preliminary. Comments welcome. We thank the Michigan Retirement Research Center (MRRC) for supporting this research through grant R-UM15-13. 


\section{Introduction}

Social Security and Medicare together accounted for 38\% of the Federal expenditures in the 2012 fiscal year. The evolution of the costs of these programs is important to the long-term fiscal balance of the Federal Government, and the very future of these programs. The Social Security Amendments of 1983 contained two key provisions that have impacted individuals' retirement decisions the most: the increases in the Full Retirement Age (FRA), which began in 2000 for those claiming benefits at 62 , and the Delay Retirement Credit (DRC), which began in 1990 for those who turned 65 in that year. If a large proportion of Older Americans, either as a reaction to those policy changes or resulting from other socio-economic or socio-demographic trends, decide to work in jobs covered by employer-provided health insurance, and then either decide to enroll in Medicare as their secondary payer or delay their enrollment into the system, the expenditures paid by Medicare will likely be lower on average per individual, as well as in total, than predicted without those policy changes.

The increases in the FRA and the DRC have likely delayed individuals' retirement to offset the considerable reduction in their Social Security benefits compared with previous cohorts. Given the linkage between claiming benefits and withdrawal from the labor market, those provisions seem to have impacted the labor supply, the health insurance (HI) coverage, and Medicare Expenditures of everyone facing retirement decisions in the last two decades, and will continue to do so in the one ahead. An important question, therefore, is whether the employment and health insurance coverage of Older Americans significantly affects Medicare costs. This question is crucial when considering the policy interaction between the Social Security and the Medicare system, through the changes in participation and health insurance coverage. However, there is little research on the Medicare costs responses to work at older ages.

Most studies have found that the reforms to the Social Security Old Age system have contributed to the increases in the Labor Force Participation Rate (LFPR) among the elderly since the mid-1990s (Pingle(2006), Blau and Goodstein (2007) (2010), Schirle (2008), DiCecio et al.(2008)); and individuals' retirement decisions will further affect their health insurance coverage, and therefore the expected Medicare Expenditures. Additionally, aggregate statistics (See Figure 1) show that the Labor Force Participation Rate of those 65 years \& over has increased during the 2002 to 2013 period, from $13.2 \%$ to $19 \%$. Notice in particular that the LFPR among individuals ages 65 to 69 is fairly high, roughly speaking, almost 1 out of 3 males is working. Even for people aged 70 to 74,1 out of 5 males is still working. Given that the LFPR is high and the trend is increasing, and likely to continue to increase given the further reforms of the 1983 Amendments to come into play in the next few years, it is very important to understand the relationship between labor supply, health insurance, and Medicare costs.

In this paper we empirically analyze the Medicare Expenditures of individuals 65 years of age and older, as a function of their Health Insurance (HI) coverage, and labor market attachment using the 1992 to 2010 waves of the Medicare Current Beneficiary Survey (MCBS). In doing so, we are able to quantify the effect of health insurance coverage of workers on Medicare Expenditures through the secondary vs. primary 


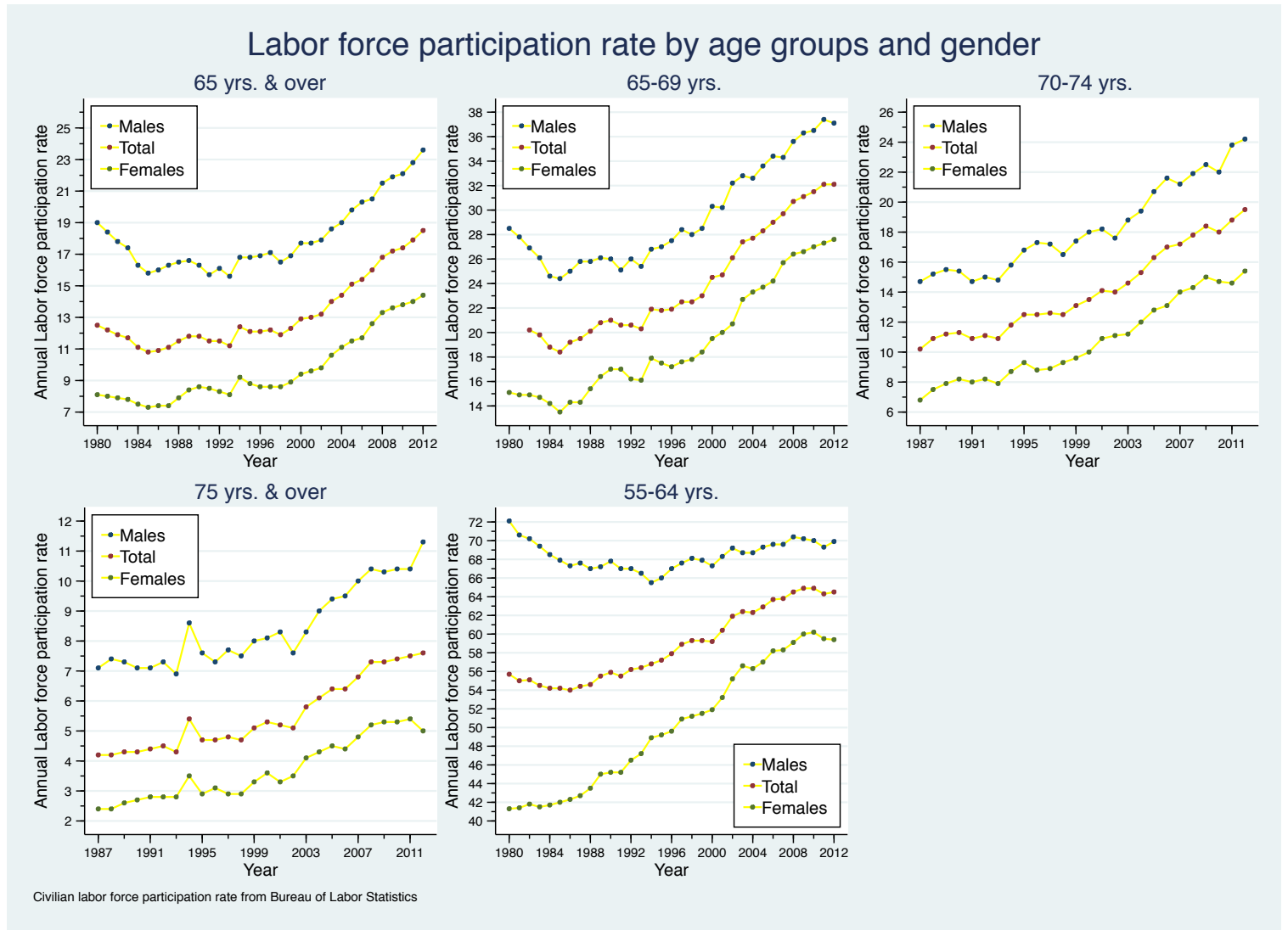

Figure 1: Civilian Labor Force Participation Rate

payer effect, and also quantify the companions savings resulting from the delay in enrollment into Medicare.

Our results find savings linked to the secondary payer effect and the delay effect of more than $\$ 3.22$ billion a year, suggesting that any future reforms to the Old Age (OA) system will have to account for the effect on Medicare expenditures of policies that likely leads to increases in employment and health coverage among populations covered by Medicare. In doing so, this research makes three contributions to the literature. First, to our knowledge, it is the first paper to address the issue of Medicare cost savings due to two aspects: the role of Medicare as a secondary payer versus primary payer, which comes into play when individuals are covered by Medicare and current employer provided health insurance from his/her own employer or his/her spouse's employer; and the Medicare cost savings resulting from the delay in Medicare enrollment beyond age 65. Second, it is the first paper to address the relationship between labor supply and Medicare costs. Rather unexpectedly the focus on Medicare for once brings good news, meaning costs savings instead of rather uncontrollable cost increases. Third, at the policy level, it is the first paper to address the effects of the past and future reforms to the Social Security system on Medicare Expenditures, at the individual and aggregate levels given the important linkages between work and Medicare Expenditures, and insurance and Medicare Expenditures.

The rest of the paper is structured as follows. Section 2 begins by presenting 
a summary of the related literature. Section 3 discusses the incentives that affect retirement, health insurance choices and Medicare Expenditures. Section 4 provides background in order to explain the connections and interactions between Medicare, the Social Security system and working decisions. Section 5 describes the data used in the analysis. Section 6 provides the empirical analysis of the determinants of Medicare Expenditures using the MCBS data sets, as well as our main findings. Section 7 shows how we calculate the Medicare savings. Section 8 provides some final discussion and the conclusions.

\section{Related Literature}

This paper builds on two strands of literature. First, the literature that analyzes Medicare expenditures, and second, the literature that studies the effects of the changes in the Social Security rules resulting from the Amendments of 1983 to the system.

Regarding the former set of efforts, Lubitz et al. (1995) and Miller (2001) examine the relationship between increasing longevity and Medicare expenditures. Lubitz et al.(1995) found that the effect on Medicare spending of increased longevity beyond the age of 65 may not be too large, and the more substantial effect comes from the increase in the absolute number of elderly people. Miller (2001) using a fixed timeuntil-death model, found that the hypothetical Medicare cost saving due to delay in morbidity, however, are not large enough to offset the Medicare solvency problem caused by population aging. Our time controls and age controls try to account for these effects.

Wennberg et al. (2002) and Zuckerman et al. (2010) address the geographical differences in Medicare spending using the MCBS. Wennberg et al. (2002) try to identify the reasons behind the geographic variation in Medicare spending, controlling for health differences and discussing the role of different practice patterns for given illnesses. They find that health differences account for $27 \%$ of the variation in Medicare spending across regions. Zuckerman et al. (2010) have similar objectives, and find that the per beneficiary Medicare spending difference between the top and bottom regional quintiles (in terms of Medicare spending) are $52 \%$, with health status accounting for $29 \%$ of this difference. After adjusting for demographic, health characteristics and changes in health status, the geographic variation is reduced to $33 \%$. Given these findings, we include regional controls in our analysis, aggregating States into nine regions.

Link et al.(1980), McCall et al.(1991), Cartwright et al. (1992), Hill et al. (1992), Christensen and Shinogle (1997), Ettner (1997), Hurd and McGarry (1997), Khandker and McCormack (1999)) have examined the relationship between Medicare supplemental insurance and Medicare expenditures, these studies are closely related to our paper in terms of focusing the role of health insurance coverage on Medicare costs. A consistent finding across the studies is that supplemental insurance choices are associated with increased Medicare expenditures, although there is no consensus on the causes, as discussed in the excellent review of the literature by Atherly (2001), some pointing to the role of adverse selection in insurance choices, and others to the 
moral hazard effect coming from the extra insurance coverage. In our estimations we include controls for availability of other insurance coverage, and later we will discuss whether our findings are in line with this literature.

Notice that none of those papers address the role of labor supply by Older Americans on Medicare Expenditures, and they do not focus on the difference for the system of having Medicare as a secondary payer versus Medicare as a primary payer, and the likely Medicare Expenditures saving from individuals delaying Medicare enrollment.

Second, this paper contributes to the literature on the overall effects of the reforms to the Social Security sytem. Gustman and Steinmeier (1983) predicted that the increase in FRA and the increase in DRC would reduce the peak in retirement at age 65 and increase LFPR of older individuals aged 65 and over. Benítez et al. (2009) concluded that the increase in the FRA would delay claiming behavior and increase labor supply at older ages. French (2005) used his structurally estimated model to simulate the increase in the FRA and found that individuals would spend three additional months to offset $20 \%$ drop in Social Security benefit. Mastrobuoni (2009) using the CPS dataset found workers reacted strongly to the increase in FRA. The affected cohorts would increase their labor supply by about half as much as the increase in the FRA, which means two months increase in FRA will result one month increase in retirement age. Pingle(2006) found that each percentage point increase in DRC led to a percentage point increase in the employment rate of men aged 65-70.

Blau and Goodstein (2007) simulate a counterfactual scenario in which the FRA is held constant at 65 for all cohorts, and the DRC is held constant at its 1983 level. Their findings indicate that the effect of increase in the FRA and the increase in DRC is quite sensitive to birth year controls. Without birth year controls, the increased FRA can explain 10\%, and the increase in DRC could explain $64 \%$ of the observed increase in LFPR at old ages, respectively. But the effect falls to $0 \%$ and $10 \%$,accordingly, with two-year birth year effects. Furthermore, using the same synthetic panel data sets, Blau and Goodstein (2010) found the increase in FRA account for between $10.5 \%$ and $20.9 \%$, and the increased DRC account for between $15.1 \%$ and $28.0 \%$ of the increase in LFPR among different birth cohort fixed effects specification. Gustman and Steinmeier (2009), Blau and Goodstein (2010) found that increased FRA, together with the increase in DRC will increase old men's labor force participation rate (about $2 \%$ to $4 \%$ in men aged from 65 to 67 in Gustman and Steinmeier and about 25\% to $50 \%$ in Blau and Goodstein).

Mitchell and Phillips (2000); Duggan, Singleton, and Song (2007); Bound, Stinebrickner, and Waidmann (2009) addressed how the increased in the FRA affects Social Security Disability Insurance (SSDI) applications, and all these papers found that it would increase SSDI applications in a range from 0.2 percentage point to 2 percentage point. Benítez-Silva and Yin (2009) found that increased FRA encouraged elderly workers to postpone OA claiming, and Song and Manchester (2007) found that an increase in the FRA of one year will decrease the probability of claiming benefits at age 62 by 8 percentage points. In our research we abstract from the Disability program, and exclude from our sample those currently on Disability or those whose benefits have converted to OA, but who entered into Medicare through the Disability program. 
Notice, again, that none of these papers address the effects of the increased FRA and the increase in DRC on Medicare costs.

\section{Policies and Incentives that affect Retirement, Health Insurance choices, and Medicare Expen- ditures}

\subsection{Increase in the Full Retirement Age and the Delay Re- tirement Credit}

The Full Retirement Age (FRA) is the earliest age at which workers can claim full, unreduced Social Security Retirement Benefits (SSRB), which are equal to the Primary Insurance Amount (PIA). Under the 1983 Social Security Amendments, the FRA was set to gradually increase from 65 to 67 over a 22-year period, which began in 2000 for those retiring at 62 . The increase in the FRA affected the cohort born in 1938 and after (see Table 1).

Table 1: Increase in Age for Receiving Full Social Security Benefits

\begin{tabular}{cc}
\hline \hline Year of Birth & Full Retirement Age \\
\hline 1937 or earlier & 65 \\
1938 & 65 and 2 months \\
1939 & 65 and 4 months \\
1940 & 65 and 6 months \\
1941 & 65 and 8 months \\
1942 & 65 and 10 months \\
$1943-1954$ & 66 \\
1955 & 66 and 2 months \\
1956 & 66 and 4 months \\
1957 & 66 and 6 months \\
1958 & 66 and 8 months \\
1959 & 66 and 10 months \\
1960 and later & 67 \\
\hline
\end{tabular}

Source: Social Security Administration

The DRC was first instituted in 1972 to provide a 1\% bonus to a person's Social Security pension to compensate for each year after the FRA a person delayed receiving benefits, up to age 72. It was increased to $3 \%$ a year in the 1977 Amendments. The Social Security Amendments of 1983 phased in an increase in the Delayed Retirement Credit (DRC) for those who claim beyond FRA, based on a persons date of birth, and lowered the age at which the increase no longer applied to 70. The increase in the DRC affected cohorts born in 1925 and after, in effect in 1990 when people born in 1925 turned 65 (see Table 2).

As we can see from Table 3, under the increased FRA and DRC, affected cohorts are facing reduction in Social Security benefits, e.g. cohort born in 1960 or after can only have 
Table 2: Increase for delayed retirement credit

\begin{tabular}{ccc}
\hline \hline Year of Birth & Monthly Rate of Increase & Yearly Rate of Increase \\
\hline 1924 or earlier & $1 / 4$ of $1 \%$ & $3 \%$ \\
$1925-1926$ & $7 / 24$ of $1 \%$ & $3.5 \%$ \\
$1927-1928$ & $1 / 3$ of $1 \%$ & $4 \%$ \\
$1929-1930$ & $3 / 8$ of $1 \%$ & $4.5 \%$ \\
$1931-1932$ & $5 / 12$ of $1 \%$ & $5 \%$ \\
$1933-1934$ & $11 / 24$ of $1 \%$ & $5.5 \%$ \\
$1935-1936$ & $1 / 2$ of $1 \%$ & $6 \%$ \\
$1937-1938$ & $13 / 24$ of $1 \%$ & $6.5 \%$ \\
$1939-1940$ & $7 / 12$ of $1 \%$ & $7 \%$ \\
$1941-1942$ & $5 / 8$ of $1 \%$ & $7.5 \%$ \\
1943 or later & $2 / 3$ of $1 \%$ & $8 \%$ \\
\hline Source: Pingle(2006), Social Security Administration
\end{tabular}

$86.6 \%$ of PIA if they retire at age 65 , they are facing $13.4 \%$ reduction of the PIA. The reduction in Social Security benefits varies across different cohorts.

Table 3: Percentage of the PIA, by Age at Which Benefits Are Claimed

\begin{tabular}{cccccc}
\hline \hline Birth Year & 62 & 65 & 66 & 67 & 70 \\
\hline 1937 & 80.0 & 100.0 & 106.5 & 113.0 & 132.5 \\
1943-1954 & 75.0 & 93.3 & 100.0 & 108.0 & 132.0 \\
1960 or later & 70.0 & 86.6 & 93.3 & 100.0 & 124.0 \\
\hline
\end{tabular}

Source: Congressional Budget Office

Because of the reduction in Social Security benefits, Social Security replacement rates-defined as benefits relative to pre-retirement earnings-are declining (Munnell (2003),(2007)). As a result, some other sources of income must rise to offset the lost benefit, which creates an incentive for older people to continue employment.

Due to the nature of the phased implementation, different cohorts are affected by these two policy changes differently, which can help us identify the effects of the DRC and the FRA. As we can see from Table D.2. in the Appendix, cohorts born before 1925 are not affected by these two changes, cohorts born between 1925 and 1938 are affected by the increase in the DRC, while cohorts born in 1938 and after are affected by both policy changes. The difference is cohort born between 1938 and 1943 face varied DRC and FRA, based on the individuals' date of birth; cohorts born in 1943 and after face the same $\mathrm{DRC}(\mathrm{DRC}=8 \%)$, but face different FRA.

\subsection{Incentives that affect Labor Supply and Health Insurance choices at older ages, and Medicare Expenditures}

The mechanisms through which the increases in participation affect Medicare expenditures are as follows. First mechanism is through Medicare becoming secondary payer instead of primary payer of the medical expenditures incurred by an individual. As we can see from Table 4, usually Medicare pays first, the only case Medicare 
will be a secondary payer is when an individual is covered by a group health plan through his/her current employer or the current employer of a spouse of any age. If due to the changes in the Social Security system, or any other socio-demographic or socio-economic reason, affected cohorts decide to work in jobs covered by employerprovided health insurance, they can decide whether or not to join Medicare at age 65 since they have to pay a premium for Medicare Part $\mathrm{B}^{1}$.

Table 4: How Medicare coordinates with other health insurance

\begin{tabular}{|c|c|c|c|}
\hline Health Insurance & Pays first & Pays second & Conditions \\
\hline $\begin{array}{l}\text { Medicare } \\
\text { Medicaid }\end{array}$ & Medicare & Medicaid & $\begin{array}{l}\text { Only pays after } \\
\text { other insurance }^{2}\end{array}$ \\
\hline Medicare & Medicare & $\begin{array}{l}\text { Current employer } \\
\text { sponsored HI }\end{array}$ & $\begin{array}{l}\text { less then } 20 \text { em- } \\
\text { ployees }^{3}\end{array}$ \\
\hline $\begin{array}{l}\text { Current employer } \\
\text { sponsored } \mathrm{HI}^{4}\end{array}$ & $\begin{array}{l}\text { Current employer } \\
\text { sponsored HI }\end{array}$ & Medicare & $\begin{array}{l}\text { more than } 20 \\
\text { employees }\end{array}$ \\
\hline $\begin{array}{l}\text { Medicare } \\
\text { Former employer } \\
\text { sponsored HI }\end{array}$ & Medicare & $\begin{array}{l}\text { Former employer } \\
\text { sponsored HI }\end{array}$ & \\
\hline Medicare & $\begin{array}{l}\text { Medicare pays for } \\
\text { Medicare covered } \\
\text { services } \\
\text { VA pays for VA } \\
\text { covered services }\end{array}$ & Don't apply & \\
\hline TRICARE & $\begin{array}{l}\text { Medicare pays for } \\
\text { Medicare covered } \\
\text { services } \\
\text { TRICARE pays for } \\
\text { services from a mil- } \\
\text { itary hospital or } \\
\text { any other federal } \\
\text { provider }\end{array}$ & $\begin{array}{l}\text { TRICARE may } \\
\text { pay second }\end{array}$ & \\
\hline \multicolumn{4}{|c|}{$\begin{array}{l}\text { Source: Center for Medicare \& Medicaid Services. } \\
{ }^{2} \text { Medicaid pays after employer group health plans, and/or Medigap insurance have paid. } \\
3 \text { If a employer joins with other employers or employee organizations (like unions) to sponsor a group health plan(called a } \\
\text { multi-employer plan), and any of the other employers have } 20 \text { or more employees, then generally Medicare is a secondary } \\
\text { insurance. } \\
\text { }{ }^{4} \text { Individual or spouse's current employer } \\
\text { Note: Apply to aged individuals covered by health insurance types in MCBS ( disabled and/or under } 65 \text { years old individuals, } \\
\text { as well as other types of health insurance not included in MCBS, please refer to "Medicare and Other Health Benefits: Your } \\
\text { Guide to Who Pays First", Center for Medicare \& Medicaid Services). }\end{array}$} \\
\hline
\end{tabular}

If those working individuals who are covered by employer-provided health insur-

\footnotetext{
${ }^{1}$ Medicare Part D, also called the Medicare Prescription drug benefit, went into effect on January 1,2006 , and also requires a premium to be covered
} 
ance decide to enroll in Medicare when they reach age 65, this public insurance system would become their secondary payer, and the per person as well as total Medicare expenditures will probably be lower compared with the case in which Medicare was the first payer. Moreover, if an individual covered by employer-provided health insurance from their working spouses, then Medicare will also be secondary instead of first payer. The second possible mechanism is the so called "crowd out" effect, namely, healthy individuals will delay Medicare enrollment when they reach 65, and Medicare would be left covering a higher percentage of unhealthy individuals, which would drive up the per person Medicare costs but lower total Medicare costs.

\section{The Medicare System and Social Security}

\subsection{Medicare}

Medicare is the federal health insurance program established by Congress in 1965 and is financed by payroll taxes on all earned income. It provides health care coverage (health insurance) for people 65 and older, people younger than 65 who have certain disabilities, and people of any age who have permanent kidney failure no matter their income. ${ }^{5}$ There were 52.3 millions Medicare beneficiaries in 2013, in which 43.5 millions are elderly and the rest 8.8 millions are non-elderly disabled beneficiaries.

Medicare has four parts: Part A, Part B, Part C and Part D. Part A is hospital insurance, which covers most medically necessary hospital stays, skilled nursing facility stays, and home health and hospice care stays. Part B is Medical Insurance, which covers most medically necessary doctor services and outpatient care. Medicare Part D is Prescription Drug Insurance, which provides outpatient prescription drug coverage. Medicare Part C, the Medicare Advantage plans, is not a separate benefit. Part $\mathrm{C}$ is the part of Medicare policy that allows private health insurance companies to provide Medicare benefits.

In this paper, since Medicare Part D became available in 2006, we will mainly focus on Medicare Part A and Medicare Part B, and we will also account for Medicare part $\mathrm{C}$ when some individuals rely on that kind of coverage. In 2008, nearly half of all Medicare beneficiaries had incomes below twice the Federal Poverty Level (FPL) ( $\$ 20,800$ for an individual and $\$ 28,000$ for a couple). For those beneficiaries, the Social Security old age benefit is the important and main source of income, and therefore more likely to be affected by any changes in the benefit structure of the OA program.

\subsection{Medicare Part A costs}

Individuals with at least 40 quarters (around 10 years) of Social Security covered employment are eligible for Medicare, at no cost for the Hospitalization Insurance component (Part A). People who worked and paid taxes for less time will pay a monthly premium for Part A, and will pay up to $\$ 426$ (the base premium) in 2014

\footnotetext{
${ }^{5}$ The latter is also referred to as End-Stage Renal Disease (ESRD), people with ESRD can get Medicare no matter how old they are.
} 
each month. The monthly amount depends on the number of quarters of Medicarecovered employment the person (or his/her spouse) has:

1) People with 30 to 39 quarters of Medicare-covered employment pay a monthly premiums of $\$ 234$ in 2014.

2) Those with less than 30 quarters of Medicare-covered employment and who are not eligible for free or reduced Medicare premiums for any other reason pay a monthly premium of $\$ 426$ in 2014 .

Besides the monthly premiums, individuals also face a Medicare Part A deductible and coinsurance costs. An important Part A component is the benefit period, which starts when the beneficiary first enters a hospital and ends when there has been a break of at least 60 consecutive days since inpatient hospital or skilled nursing care was provided. There is no limit to the number of benefit periods covered by Part A during a beneficiary's lifetime; however, inpatient hospital care is normally limited to 90 days during a benefit period, and copayment requirements apply for days 61 through 90. For example, in 2014, the initial deductible for Hospital Benefits is $\$ 1,260$, and the daily co-insurance is $\$ 0$ for the first 60 days, and from the $61^{\text {st }}$ to $90^{\text {th }}$ days, the daily co-insurance is $\$ 315$. If a beneficiary exhausts the 90 days of inpatient hospital care available in a benefit period, the beneficiary can elect to use days of Medicare coverage from a nonrenewable "lifetime reserve" of up to 60 (over life time) additional days of inpatient hospital care. In 2014, the coinsurance is $\$ 630$ per each "lifetime reserve day" after day 90 for each benefit period. And individuals will pay all costs beyond lifetime reserve days for each benefit period.

Medicare Part A provides 100\% of expenses for the first 20 days of skilled nursing care. The daily co-insurance rate is $\$ 157.5$ from day 21 to day 100 . And there will be no benefits starting the 101st day.

\subsection{Medicare Part B costs}

Medicare Part B is the program that covers doctors services and outpatient care. The standard Medicare Part B premium is determined by a formula contained in the 1997 Balanced Budget Act, which set the premium at 25 percent of total program costs. The remaining 75 percent of program costs are financed through general revenues. The Medicare Modernization Act of 2003 (MMA) requires higher-income beneficiaries to pay a higher percentage of program costs, resulting in multiple tiers of premiums based on income, and this started its implementation in $2007 .{ }^{6}$. Less than $5 \%$ people pay a higher premium. ${ }^{7}$ The standard Part B premium is $\$ 104.90$ each month in 2014. Individuals also face a \$147 Part B deductible in 2014.

Most individuals have the premium for their Part B coverage deducted from their Social Security, Railroad Retirement, or Federal government retirement checks. The Social Security Act stated that if a person is enrolled in both Part B and Social Security, the Part B premium must be deducted from the person's Social Security

\footnotetext{
${ }^{6}$ Higher-income beneficiaries pay monthly Part B premiums equals to $35,50,65$ or 80 percent of the total cost. See SSA(2011)

${ }^{7}$ The income thresholds used to calculate Part B income-related premiums are frozen at 2010 levels for the 2011 through 2019 period.
} 
check. In order to provide a basic level of protection from rapidly accelerating health care costs, a "hold-harmless" provision in the Social Security Act mandates that the Part B premium increase cannot exceed any beneficiaries cost-of-living adjustment (COLA) in their Social Security check. As a result, the net amount of the individuals Social Security check from one year to another does not decrease.

\subsection{Late enrollment Penalty and Special Enrollment Period}

Notice that Medicare is actually a voluntary program for Americans 65 years old or older who are eligible, but it contains a number of provisions related to late enrollment penalties, Special Enrollment Periods and effective years.

3) If an individual does not sign up for Part B when he is first eligible, he has to pay a late enrollment penalty, with some exceptions we will discuss below. The penalty is an increase of 10 percent in the Part B premium for each 12-month period he delays enrollment in Medicare Part $\mathrm{B}^{8}$. The penalty is based on the standard Part $\mathrm{B}$ premium and tied to the monthly premium. There is no end to the Medicare Part B late enrollment penalty. Individual will carry this penalty with his Medicare costs for as long as he has Medicare Part B.

2) A special enrollment period (SEP) is available, effective November 1984, for individuals age 65 or over who did not enroll in SMI, ${ }^{9}$ when first eligible (or who terminated SMI enrollment because of coverage under a group health plan (GHP) based on their own or a spouse's current employment status). These individuals may enroll in SMI anytime while covered under the GHP or during the 8-month period immediately following the last month of GHP coverage based on current employment status.

3) In 1985: Premium-paying individuals who do not purchase Part A coverage within a specific time after becoming eligible because of age are subject to a 10percent penalty for each 12 months they are late in enrolling ${ }^{10}$. There is a cutoff on the length of time these individuals will have to pay an enrollment penalty. The 10percent premium penalty would be limited to twice the number of years enrollment was delayed. Therefore, if enrollment were delayed 1 year, the penalty would be assessed for 2 years. Individuals in this category and already enrolled will have the length of time the higher premium was paid credited to them.

Under the provision of SEP and GHP, if an individual or his spouse is still working and receiving current employer insurance coverage from an employer with 20 or more employees, then he is qualify for a Special Enrollment Period and will not be penalized by a late enrollment fee. During the Special Enrollment Period, individual can enroll in Part A and/or Part B without penalty. This Special Enrollment Period allows individual to enroll in Part A and/or Part B at anytime while he or his spouse are

\footnotetext{
${ }^{8}$ If an individual were to delay Part B enrollment for 30 months, since this included only 2 full 12 -month periods, the Part B premium penalty is $20 \%$.

${ }^{9}$ Supplementary Medical Insurance, which in the past was also known simply as Part B and now consists of Part B and Part D.

${ }^{10}$ Individuals who are eligible for free Part A can sign up for Part A any time during or after his/her Initial Enrollment Period starts.
} 
still working and for up to eight months after individual loses his employer coverage or stop working.

It is important to note that COBRA and retiree insurance are not considered current employer insurance, and individuals will not have a Special Enrollment Period if he has COBRA or retiree insurance.

\subsection{Social Security Old Age Benefits}

When an individual works and pay Social Security taxes, he or she earns credits towards Social Security benefits. Individuals need 40 credits (about 10 years of work) if they were born in 1929 or later. And 40 quarters is the maximum requirement. Individuals can first apply for OA Social Security benefits at age 62, although with a reduction, and the latest they can claim while still receiving an upward adjustment (called Delayed Retirement Credit, DRC) is age 70. Upon applying the individual receives benefits until death. The individuals OA benefit, depends on his Average Indexed Monthly Earnings (AIME), which is then used to compute the Primary Insurance Amount (PIA). The AIME is roughly his average monthly income during his 35 highest earnings years in the labor market, and the PIA is the potential Social Security benefit rate for retiring at the FRA. If an individual retires earlier or later than FRA, he will receive less or more than the $100 \%$ of the PIA accordingly.

The PIA is the sum of three separate percentages of portions of the AIME. While the percentages of this PIA formula are fixed by law, the dollar amounts in the formula change annually with changes in the national average wage index. These dollar amounts, called 'bend points', govern the portions of the AIME. The bend points in the year 2015's PIA formula, $\$ 826$ and $\$ 4,980$, apply for workers becoming eligible in 2015. The fixed percentages are $90 \%, 32 \%$ and $15 \%$. The AIME is converted into a Primary Insurance Amount (PIA) using the following formula:

$P I A_{t}=\left\{\begin{array}{lc}0.9 \times A I M E_{t} & \text { if } A I M E_{t}<\$ 826 \\ \$ 743.4+0.32 \times\left(A I M E_{t}-\$ 826\right) & \text { if } \$ 826 \leq A I M E_{t}<\$ 4,980 \\ \$ 2,072.68+0.15 \times\left(A I M E_{t}-\$ 4,980\right) & \text { if } A I M E_{t} \geq \$ 4,980\end{array}\right.$

which represents the monthly Old Age Social Security benefit received by a given individual. The maximum benefit for someone claiming benefits at the FRA is $\$ 2,663$.

\subsection{Interactions between OA benefits, Medicare, and work decisions}

1) OA benefits and Medicare

If an individual is already receiving OA benefits when he turns 65, he will get both Medicare Part A and Part B automatically. If individuals are not collecting Social Security when they become eligible for Medicare, they must enroll through Social Security. If an individual wants to receive OA at 65 but delay enroll in Medicare, he has to talk to Social Security also. 
2) OA benefits and work decisions

An individual can continue to work and still receive retirement benefits. Individual's earnings in (or after) the month he reaches his full retirement age will not reduce his Social Security benefits. However, his benefits will be reduced if his earnings exceed certain limits for the months before he reaches his full retirement age. Every $\$ 1$ in benefits will be deducted for each $\$ 2$ in earnings individual has above the annual limit if he is younger than the FRA. In the year the individual reaches his FRA, his benefits will be reduced $\$ 1$ for every $\$ 3$ he earns over an annual limit until the month individual reaches his FRA. In 2015, the lower amount is $\$ 15,720$ and the higher amount is $\$ 41,880$.

3) Medicare and work decisions

As discussed above, there is a Part A and/or Part B penalty for individuals who delay enrollment in Medicare and do not have GHP. For individuals who have GHP as their primary insurance, they qualify for the SPE and will not be penalized by a late enrollment fee. So individual's work decision will influence his/her Medicare enrollment decision as well as his/her Medicare premium payments.

\section{$5 \quad$ Data and Summary Statistics}

We use the 1992 to 2010 Medicare Current Beneficiary Survey (MCBS) Cost and Use research files in the analysis. The MCBS is a rotating panel of a nationally representative sample of Medicare beneficiaries conducted by the Centers for Medicare and Medicaid Services (CMS). MCBS has two series of data files, the Access to Care series and the Cost and Use series. MCBS produces data for both cross-sectional and longitudinal analysis. For the purpose of this research, we are using the Cost and Use series.

The Cost and Use research files provide information on individual level premiums, health insurance coverage and usage, Medical expenditures by provider and service type, Medicare entitlement information, health status and functioning, date of death, Medicare status and Medicare claims for survey participants. Medicare status can help us identify whether a Medicare beneficiary is aged or disabled or ESRD, ${ }^{11}$ and in this research, we will only focus on aged people. Medicare entitlement start and end date will help us identify when a individual enrolls in Medicare and stays in Medicare. A great advantage of MCBS is that the data provided is the product of matching survey data with true Medicare claim data. This kind of matching can adjust for underreporting of the use of health care services by survey respondents and to fill gaps and make corrections in the survey expenditure data. So the MCBS is probably the best source of information on Medicare expenditures.

Table 5 describes the type of sample restrictions we have put together to obtain the sample we use. In MCBS, there is only one dummy variable captures the sample

\footnotetext{
${ }^{11}$ Individuals enrolled in Medicare due to disability or ESRD (all of them coming from the DI program) are of very different ages and with an extremely low attachment to the labor force. Their health expenditures and Medicare expenditures deserve a separate analysis, and therefore we have excluded them from our sample.
} 
person's working status, which takes value 1 if sample person is currently working at a job or business and takes value 0 if not working. And this variable is first available in 1999. Given that our goal is to link the labor market attachment, health insurance coverage and the Medicare expenditures of elderly individuals around retirement age, the full sample used in our analysis is 1999-2010 MCBS Cost and Use Research Files. The total observations are 145,578, in which 110,467 are aged Medicare beneficiaries. We lost $8.3 \%$ of those observations as a result of missing information on working status. And we left with 101,336 cases.

$99.4 \%$ of these 101,336 observations are alive after 6 months being first observed. The consideration here is that Medicare spending is highly skewed. Typically, 25\% of beneficiaries account for $85 \%$ of program spending (CBO, 2005), And individuals usually generating the highest amount if medical expenditure during the last 6 months of their lives ${ }^{12}$. We lost $6 \%$ of those observations as a result of missing information on health related variables, demographic variables, and health insurance indicators, leaving 95,111 cases $^{13}$. After excluding observations who are not working at the time of the interview but covered by health insurance from his/her current employer ${ }^{14}$, we are left with 93,911 observations, which is the estimation sample in the paper.

Table 5: Selection of the Estimation Sample

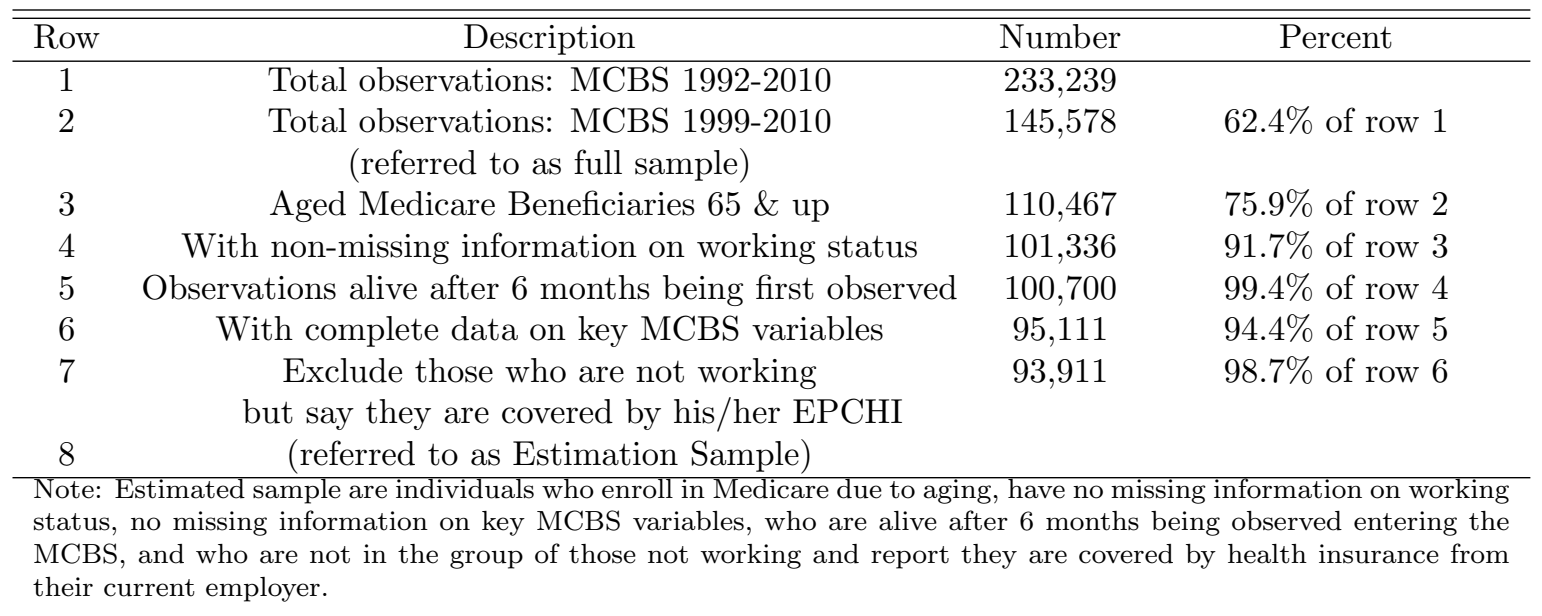

\subsection{Total Health Expenditures and Medicare Expenditures}

The MCBS has very detailed information on medical expenditures by provider and service type. For the purpose of our study, we will focus on the following three

\footnotetext{
${ }^{12}$ If we were to include those individuals, the analysis would be dominated by the determinants of the costs in those last months of life. We will be studying those individuals separately in a companion paper

${ }^{13}$ Those sample person who has missing information on health related variables such as self reported health status are those who finished a facility interview, they also have missing information on working status. Those person are those who generate high Medicare costs, We will study those person separately in another paper

${ }^{14}$ That might due to temporarily on leave, at vacation, on sick. etc.
} 
types of medical expenditures: total health expenditures of an invidual ${ }^{15}$, Medicare Expenditures ${ }^{16}$, and out-of pocket expenditures ${ }^{17}$. Related Medicare Expenditures information including: annual Part A premium, annual Part B premium, annual total premiums for all secondary health insurances, annual inpatient coinsurance and annual skilled nursing facility (SNF) coinsurance. We use CPI to adjust all medical expenditures to 2009 dollars.

As we can see from Table 6, individuals with less than 10 years Social Security covered employment are the ones paying a high annual Medicare Part A premiums ${ }^{18}$ which is more than twice as much as the average Out of Pocket expenditures of the average individual in our sample. The reason that the weighted average Part A reimbursement is higher than the weighted average Medicare Expenditures is because the average is over the sample persons who have positive values in those variables. The weighted population who have positive Part A reimbursement is around $18 \%$ of the weighted population who has positive Medicare Expenditures.

\section{$5.2 \quad$ Medicare enrollment status}

Notice that, if a sample person was originally entitled to Medicare due to disability, once they turn 65, they will be coded as aged. In order to solve this issue, we construct the enrollment year and enrollment month variables using the information on individual's date of birth as well as his Medicare enrollment date. The Medicare 7 months initial enrollment period is 3 months before an individual turns 65, the month he turns 65 and 3 months after he turns 65, and we keep in our sample respondents whose Medicare enrollment age is 64 years and 9 months or later. We then classify the aged Medicare beneficiaries into two mutually exclusive categories: enroll at initial enrollment period, and delay enrollment. Then, using Medicare enrollment year as well as Medicare enrollment month, we can distinguish whether an individual's enrollment falls into his initial enrollment period or not. Furthermore, if a individual falls into his delay enrollment period, we would able to further calculate how long (both in years and in months) has he delayed his Medicare enrollment.

Table 7 shows the weighted delay Medicare enrollment distribution based on two estimation samples: columns 3 to 5 are calculated from full estimation sample, and the last three columns are calculated from the subsample conditional on observations who have health insurance through current employer. 94.96\% of our full estimation sample has both Medicare Part A and Part B, of those $3.71 \%$ delayed their Medicare Part A and Part B enrollment. There are also small percentage of individuals in

\footnotetext{
${ }^{15}$ total health expenditures include coverage from 11 potential sources: Medicare fee-for service, Medicare HMOs, Medicaid, employer-based private health insurance, individually purchased private health insurance, private insurance managed care, private insurance from unknown sources, the VA and other public insurance, OOP payments, and uncollected liability.

${ }^{16}$ Equal payments for fee-for-service beneficiaries, annual capitation payments to Medicare Advantage plans and pass-through expenses for inpatient hospital services.

${ }^{17}$ Including coinsurance amounts, copayments, deductibles, balance billings, and charges for nonMedicare covered services not paid for by public or private insurance plans.

${ }^{18}$ They are around $0.076 \%$ of the weighted population in the estimation sample, which represents around 0.28 millions Medicare beneficiaries.
} 
Table 6: Average weighted Medical Expenditures and premiums

\begin{tabular}{lccc}
\hline \hline Variables & Female & Male & Total \\
\hline Premium_A & $\$ 4,016.9$ & $\$ 4,047.3$ & $\$ 4,032.9$ \\
& $(1,963.6)$ & $(1,709.6)$ & $(1,814.2)$ \\
Premium_B & $\$ 998.4$ & $\$ 1,003.5$ & $\$ 1,000.6$ \\
& $(234.2)$ & $(240.6)$ & $(237)$ \\
Premium_T & $\$ 1,929.4$ & $\$ 1,784.7$ & $\$ 1,868.1$ \\
& $(1,503.9)$ & $(1,475.6)$ & $(1,493.7)$ \\
Coinsurance_INP & $\$ 10,142.9$ & $\$ 6,902.4$ & $\$ 8,467.1$ \\
& $(10,865)$ & $(8,797)$ & $(9,948.9)$ \\
Coinsurance_SNF & $\$ 3,136.5$ & $\$ 3,202.1$ & $\$ 3,158.7$ \\
& $(2,831.5)$ & $(2,901.7)$ & $(2,854.3)$ \\
Total Health & $\$ 10,933$ & $\$ 11,414.5$ & $\$ 11,136.3$ \\
Expenditures & $(19,397)$ & $(21,974.2)$ & $(20,526.2)$ \\
Medicare & $\$ 6,927.5$ & $\$ 7,579.6$ & $\$ 7,194.4$ \\
$\quad$ Expenditures & $(15,112.1)$ & $(17,135)$ & $(15,974.1)$ \\
Employer Provided HI & $\$ 2,973.3$ & $\$ 3,047.4$ & $\$ 3,006.7$ \\
$\quad$ Expenditures & $(8,457.3)$ & $(8,747.4)$ & $(8,589.4)$ \\
Out of Pocket & $\$ 1,897.3$ & $\$ 1,798$ & $\$ 1,855.4$ \\
$\quad$ Expenditures & $(4,805.2)$ & $(4,167.2)$ & $(4,547.1)$ \\
Part A & $\$ 18,161.1$ & $\$ 19,425.9$ & $\$ 18,703.8$ \\
$\quad$ Reimbursement & $(21,667.6)$ & $(25,010.2)$ & $(23,168.5)$ \\
Part B & $\$ 3,588.6$ & $\$ 3,930.8$ & $\$ 3,728$ \\
$\quad$ Reimbursement & $(6,198.2)$ & $(6,899.3)$ & $(6,495.1)$ \\
Income & $\$ 27,065.7$ & $\$ 38,752.6$ & $\$ 32,036.7$ \\
& $(45,841.7)$ & $(76,854.4)$ & $(61,264.1)$ \\
\hline \hline
\end{tabular}

Note: Premium_A = Annual premium for Medicare Part A; Premium_B $=$ Annual premium for Medicare Part B; Premium_ $\mathrm{T}=$ Annual total health insurance premium for all secondary health insurance; Coinsurance_INP: inpatient coinsurance; Coinsurance_SNF: skilled nursing facility coinsurance. All expenditures and costs are over sample person who have non-zero values. Expenditures and costs are in 2009 dollars. Statistics are calculated using cross-section sample weights. Standard deviations are in parentheses. Number of observations varies by variable and sample.

our full estimation sample who only have Part A coverage (4.14\%) or only Part B coverage (0.09\%). For those who have only Part A coverage, $9.29 \%$ delayed their Part A enrollment, while $51.4 \%$ of individuals who only have Part B coverage delayed their Part B enrollment. In general, male are more likely to delay enrollment in Medicare, part of that can be explained by the fact that male has higher labor force participation rate then female at age 65 and up (see Figure 1). When conditional on having EPCHI, we see a higher percentage of delay enrollment compared with the full estimation sample. This shows that working as well as health insurance are related to more delay enrollment because individuals have a bigger incentive to do so. However, for Medicare Part A things are bit different, the reason might be that free Part A requires enough working quarters, and those who have EPCHI are more likely to qualify for free Part A compared with those who don't. So those who don't qualify for free Part A might delay enrollment more given the premium situation. 
Table 7: Weighted Delay Medicare Enrollment distribution

\begin{tabular}{|c|c|c|c|c|c|c|c|}
\hline \multirow[b]{2}{*}{ Variables } & \multirow[b]{2}{*}{ Percent } & \multicolumn{3}{|c|}{ Full Estimation Sample } & \multicolumn{3}{|c|}{ Conditional on having EPCH] } \\
\hline & & All & Female & Male & All & Female & Male \\
\hline Medicare A \& B & $94.96 \%$ & 3.71 & 3.4 & 4.14 & 4.52 & 3.81 & 5.1 \\
\hline Medicare Part A & $4.14 \%$ & 9.29 & 8.65 & 9.72 & 7.35 & 6.9 & 7.67 \\
\hline Medicare Part B & $0.09 \%$ & 51.4 & 50 & 54.33 & 87.77 & 85.45 & XX?? \\
\hline
\end{tabular}

\subsection{Health, demographic and employment variables}

The information on employment status in the MCBS is very limited, there is only one variable capturing whether a sample person is currently working for a job or business. In contrast, the MCBS has a rich set of health measures and demographic information. The health measures include self-reported health status, activities of daily living (ADLs), Instrumental Activities of Daily Living(IADLs), cancers, and chronic diseases. The self-reported health status takes values 1 to 5 , and each value corresponding to excellent, very good, good, fair and poor accordingly. In the MCBS, individuals also provide health information on health transitions by answering question "Compared to one year ago, how would you rate (your/spouse's) health in general now? Would you say (your/spouse's) health is much better now, somewhat better now, about the same, somewhat worse, or much worse now".

Table 8 provides some descriptive statistics for the EPCHI and no EPCHI sample. There are significant differences between the EPCHI and no EPCHI subsamples in gender, age, educational attainment, marital status, working status as well as health status. Notice that age in our estimation is top coded, observations who are age 90 and over are coded as age 90 .

\subsection{Health Insurance}

Due to the nature of the MCBS, individuals in the sample have at least Medicare coverage. Moreover, individuals could have one or more health insurance coverages other than Medicare. We first classify individuals into two mutually exclusive health insurance categories: have employer provided health insurance (EPHI) regardless of other health insurance coverage, and don't have any source of EPHI. There are 39.2\% (weighted) of sample persons who have employer provided health insurance (EPHI). We then further classify individuals who have EPHI into one of the following three mutually exclusive categories according to the source of EPHI: current employer provided HI (EPCHI $)^{19}$; retiree HI (EPRHI ${ }^{20}$; as well as other employer provided health insurance (EPUHI) ${ }^{21}$. Among EPEHI, EPRHI and EPUHI, we further categorize individuals according to whether they get employer provided health insurance through themselves or through their spouses. Cases with multiple sources of insurance are

\footnotetext{
${ }^{19}$ Main insured person(MIP)'s current employer, or from family business.

${ }^{20}$ MIP's prior employer or deceased spouse's employer.

${ }^{21}$ Union, AARP, fraternal/professional organization, deceased spouse's union.
} 
Table 8: Descriptive Statistics of Selected Variables

\begin{tabular}{|c|c|c|c|}
\hline \multirow[b]{2}{*}{ Variables } & \multicolumn{2}{|c|}{ By EPCHI Status } & \multirow[b]{2}{*}{ All } \\
\hline & No EPCHI & EPCHI & \\
\hline \multirow[t]{2}{*}{ Age } & 75.17 & 69.45 & 74.99 \\
\hline & $(7.01)$ & $(4.38)$ & $(7.03)$ \\
\hline \multirow[t]{2}{*}{ Male } & 0.42 & 0.56 & 0.43 \\
\hline & $(0.49)$ & $(0.49)$ & $(0.49)$ \\
\hline \multirow[t]{2}{*}{ Married } & 0.56 & 0.72 & 0.57 \\
\hline & $(0.49)$ & $(0.45)$ & $(0.49)$ \\
\hline \multirow[t]{2}{*}{ Black } & 0.08 & 0.08 & 0.08 \\
\hline & $(0.26)$ & $(0.27)$ & $(0.26)$ \\
\hline \multirow[t]{2}{*}{ Hispanic } & 0.02 & 0.007 & 0.02 \\
\hline & $(0.14)$ & $(0.08)$ & $(0.13)$ \\
\hline \multirow[t]{2}{*}{ High School } & 0.30 & 0.23 & 0.29 \\
\hline & $(0.45)$ & $(0.43)$ & $(0.46)$ \\
\hline \multirow[t]{2}{*}{ Some College } & 0.25 & 0.29 & 0.25 \\
\hline & $(0.43)$ & $(0.45)$ & $(0.43)$ \\
\hline \multirow[t]{2}{*}{ College } & 0.11 & 0.16 & 0.11 \\
\hline & $(0.31)$ & $(0.36)$ & $(0.31)$ \\
\hline \multirow[t]{2}{*}{ Excellent Health } & 0.17 & 0.27 & 0.18 \\
\hline & $(0.38)$ & $(0.44)$ & $(0.38)$ \\
\hline \multirow[t]{2}{*}{ Very Good Health } & 0.31 & 0.35 & 0.32 \\
\hline & $(0.46)$ & $(0.47)$ & $(0.46)$ \\
\hline \multirow[t]{2}{*}{ Good Health } & 0.33 & 0.27 & 0.32 \\
\hline & $(0.46)$ & $(0.44)$ & $(0.46)$ \\
\hline \multirow[t]{2}{*}{ Working } & 0.13 & 0.77 & 0.15 \\
\hline & $(0.33)$ & $(0.42)$ & $(0.35)$ \\
\hline
\end{tabular}

assigned to categories in the order shown in the table. For example, a respondent who is covered by EPCHI and EPRHI is assigned to EPCHI.

Then the individuals without EPHI are classified into the following mutually exclusive health insurance categories: original Medicare only, Medicare HMO only, Medicare HMO with other health insurance ${ }^{22}$, private HMO, Medigap, Medicaid, and other public health insurance (Such as Tricare and VA). Cases with multiple sources of insurance are assigned to categories in the order shown in the table. For example, a person with both Medigap and Medicaid is assigned to Medigap.

Table 9 shows the weighted Medicare Expenditures by health insurance categories, and provides the evidence that health insurance matters is correlated with Medicare Expenditures. Respondents with EPHI on average generate less expenditures compared with those without EPHI. Among individuals who have EPHI, those covered by EPCHI are the ones that generate the least amount of expenditures. Among those without EPHI, respondents covered by original Medicare-Only generate less costs compared to those who have any other health insurance coverage, except for individuals who are covered by Medicare HMO (Medicare HMO, Medicare HMO +

\footnotetext{
${ }^{22}$ One or more of the following: Medigap, Medicaid, Other public HI.
} 
Table 9: Medicare Expenditures by Health Insurance Category

\begin{tabular}{l|lll}
\hline Variable & Percentage & Weighted Mean & Standard Deviation \\
\hline \hline EPHI & $38.8 \%$ & $\$ 7,134.6$ & $\$ 15,721.1$ \\
\hline EPCHI_r & $2 \%$ & $\$ 3,046.2$ & $\$ 8,744.1$ \\
EPCHI_s & $1.1 \%$ & $\$ 4,705.8$ & $\$ 19,857.0$ \\
EPRHI_r & $25.6 \%$ & $\$ 7,446.8$ & $\$ 16,167.5$ \\
EPRHI_s & $5.7 \%$ & $\$ 6,674.3$ & $\$ 13,841.0$ \\
EPUHI_r & $4.2 \%$ & $\$ 7,205.2$ & $\$ 15,944.0$ \\
EPUHI_s & $0.2 \%$ & $\$ 8,074.1$ & $\$ 15,272.0$ \\
\hline No EPHI & $61.2 \%$ & $\$ 7,237.4$ & $\$ 16,153.2$ \\
\hline Original Medicare & $5.7 \%$ & $\$ 5,891.4$ & $\$ 14,030.3$ \\
Medicare HMO & $13.1 \%$ & $\$ 2,520.5$ & $\$ 6,615.4$ \\
Medicare HMO + OHI & $6.2 \%$ & $\$ 4,965.6$ & $\$ 11,477.1$ \\
Private HMO & $5.4 \%$ & $\$ 6,783.0$ & $\$ 14,537.5$ \\
Medigap & $23.1 \%$ & $\$ 7,968.5$ & $\$ 16,309.1$ \\
Medicaid & $6.8 \%$ & $\$ 12,225.1$ & $\$ 23,837.5$ \\
Other Public & $0.9 \%$ & $\$ 8,117.5$ & $\$ 17,989.5$ \\
\hline \multicolumn{7}{l}{ Total } & $100 \%$ & $\$ 7,194.4$ & $\$ 15,974.1$ \\
\hline Note: OHI: other health insurance. EPCHI_r: health insurance through respondents' own \\
current employer; EPCHI_s: health insurance through respondents' spouse's current em- \\
ployer; EPRH_r. health insurance through respondents 'own former employer; EPRHI_s: \\
health insurance through respondents' spouse's former employer. Average Medicare Exp. \\
are over observations who have positive expenditures. Statistics are calculated using cross- \\
section sample weights. Number of observations varies by variable and sample.
\end{tabular}

(ther $)^{23}$.

Table 10 presents additional evidence that both working and health insurance are correlated with Medicare Expenditures. The table summarizes Medicare Expenditures, Total health expenditures, as well as out of pocket expenditures, by working status, EPCHI status, also conditional on age and health status. The full estimation sample is divided into 4 subgroups: (working, no EPCHI), (working, EPCHI), (not working, no EPCHI), (not working, EPCHI). There are three aspects we need to pay attention. 1) Workers with EPCHI generate less costs to the Medicare system compared with workers without EPCHI. For individuals who are 65 to 69 years old, and in good health, the weighted average Medicare Expenditures is $\$ 3,179.2$ for workers without EPCHI and $\$ 3843.9$ for non-workers without EPCHI, a difference of $\$ 664.7$. The $\$ 664.7$ is mainly the effect of working on Medicare costs, if we take into account of the effect of EPCHI on Medicare Expenditures, then the differences is increased to $\$ 2148.1$ (\$3843.9-\$1695.8), so the pure health insurance effect on total Medicare expenditure would be $\$ 1483.4$. The effect of EPCHI is more than twice the effect of working on total Medicare costs. These differences are larger for individuals who are

\footnotetext{
${ }^{23}$ Medicare HMO enrollees seem to be a fairly selected sample of individuals given the nature of the Medicare-HMO insurance coverage which provides some kind of insurance against excessive out of pocket expenditures, which can occur in the standard Medicare system.
} 
in bad health. 2) Workers covered by $\mathrm{EPCHI}^{24}$ generate less Medicare Expenditures, but they have higher Total health expenditures as well as out of pocket expenditures regardless of health status. This suggests that workers covered by EPCHI are not necessarily low medical costs generators, it is the result of Medicare appearing only as a secondary payer. 3) For those who are not working but are covered by EPCHI are getting coverage through their spouses' current employer, and they have the least amount of out of pocket expenditures of all the 4 subgroups regardless of health status. They also have higher Medicare Expenditures and Total health expenditures compared with those who are working, which suggests those people are high Medical costs generators, but they are taking actions to minimize their out of pocket expenditures.

Table 10: Medical Expenditures, by Health Insurance and Working status

\begin{tabular}{lcccc}
\hline \hline & \multicolumn{2}{c}{ Working } & \multicolumn{2}{c}{ Not Working } \\
\cline { 2 - 5 } & No EPCHI & EPCHI & No EPCHI & EPCHI \\
\hline Medicare Expenditures & & & & \\
Age $=65 \sim 69$, Good Health & & & & \\
$\quad$ Mean & $\$ 3179.2$ & $\$ 1695.8$ & $\$ 3843.9$ & $\$ 3805.8$ \\
$\quad$ Standard Deviation & $\$ 7152.5$ & $\$ 6478.6$ & $\$ 9820.3$ & $\$ 13543.8$ \\
Age $=65 \sim 69$, Bad Health & & & & \\
Mean & $\$ 8714.9$ & $\$ 2051.8$ & $\$ 13238.1$ & $\$ 7169.1$ \\
$\quad$ Standard Deviation & $\$ 19393.8$ & $\$ 2123.6$ & $\$ 27240.5$ & $\$ 40590.3$ \\
\hline \hline Total Health Expenditures & & & & \\
Age $=65 \sim 69$, Good Health & & & & \\
$\quad$ Mean & $\$ 5296.6$ & $\$ 5683.6$ & $\$ 6524.8$ & $\$ 6829.0$ \\
$\quad$ Standard Deviation & $\$ 8576.2$ & $\$ 10897.3$ & $\$ 12188.2$ & $\$ 14279.5$ \\
Age $=65 \sim 69$, Bad Health & & & & \\
Mean & $\$ 11445.8$ & $\$ 13388.3$ & $\$ 18253.4$ & $\$ 12723.5$ \\
$\quad$ Standard Deviation & $\$ 21444.4$ & $\$ 35378.7$ & $\$ 38586.8$ & $\$ 40926.8$ \\
Out of Pocket Expenditures & & & & \\
Age $=65 \sim 69$, Good Health & & & & \\
Mean & $\$ 1268.2$ & $\$ 1410.1$ & $\$ 1385.4$ & $\$ 1072.6$ \\
Standard Deviation & $\$ 2097.0$ & $\$ 2134.8$ & $\$ 3032.3$ & $\$ 1782.4$ \\
Age $=65 \sim 69$, Bad Health & & & & \\
Mean & $\$ 2115.4$ & $\$ 3176.6$ & $\$ 2077.7$ & $\$ 1679.6$ \\
Standard Deviation & $\$ 5270.1$ & $\$ 10756.6$ & $\$ 5066.4$ & $\$ 3039.0$ \\
\hline \hline
\end{tabular}

Note: All expenditures are in 2009 dollar.

\subsection{Capturing the changes in the FRA and the DRC}

Since different cohorts are affected by DRC and FRA differently (see Table 18), we are able to identify and separate the effect of DRC and FRA for some cohorts.

\footnotetext{
${ }^{24}$ Either through their own or their spouses' current employer.
} 
We construct dummy variables indicating the effects of DRC and/or FRA for each respondent in the sample according to their birth year, DRC and FRA rules (Table 1, Table 2). Cohorts born in 1925 and 1937 are only affected by DRC, and DRC3.5 is a dummy indicating cohorts born in 1925 to 1926 and facing 3.5\% DRC. Cohorts born in 1938 and after are affected by both DRC and FRA. DRC6.5_FRA2 is a dummy indicating cohort born in 1938 and facing 6.5\% DRC and FRA is 65 and 2 months, similarly, DRC7.0_FRA4 represents cohorts born in 1939 and facing DRC is 7\% and FRA is 65 and 4 months. Due to data limitation, the youngest cohorts we are able to observe in MCBS is cohorts born in 1945, whose DRC is $8 \%$ and FRA is 66.

\section{Health Insurance and Medicare Expenditures: Empirical Analysis}

\subsection{Model specifications}

In order to estimate how insurance plans affect medical expenditures, several models have been proposed and used in the previous literature, trying to consider the best model to use for a set of data that shows a considerable portion of the population does not incurred in health expenditures in any given year, and among those who have positive health expenditures, these are highly skewed and have a long right tail. Additionally, even if total health expenditures are positive, other expenditures, like those paid by the Medicare system are also often observed to be true zeros.

Ordinary Least Squares estimation is simple and easy to interpret but can be problematic to use when the data contains a relatively large number of zeros. The Two-Part model (Duan et al.(1983), Dow and Norton(2003), Albouy et al. (2010)), has all the advantages of the OLS while still acknowledging that the zeros are not the product of choice but are actual absence of expenditures, and is the most widely used when analyzing Medicare expenditures, and in particular using the MCBS data sets, (Khandker and McCormack(1999), Atherly(2002)). The sample selection model (following Heckman (1979), presented by Dow and Norton (2003), Chaze (2005), Albouy et al. (2010)) has also been proposed but is unclear whether is the most appropriate specification given that a level of zero expenditures is hardly a choice made by the individuals, and the Tobit model (Griswold et al. (2004), Chaze (2005), Keane and Stavrunova (2011)) is also problematic since the zeros we observe in the health expenditures process are true zeros not the product of censoring. Finally, if possible the specifications should consider panel data specifications, which is not always possible given the nature of the data used.

As we can see from Table 11, where we can observe a certain proportion of population with zero Medicare expenditures, the weighted proportion of the population who has zero spending is almost $19 \%$. Notice that the zero Medicare expenditures are true zeros, those true zeros either come from some individuals not generating any expenditures at any given year, or situation in which they generate health expenditures but other health insurance(s), other than Medicare, paid for them. So the zeros in the sample are not the product of a censoring or a selection problem. It is 
important to mention that Medicare expenditures are highly left skewed, so typically, $25 \%$ of beneficiaries account for $85 \%$ of program spending (CBO, 2005). Given the data in the sample has such characteristics, I will use two part model in the regression analysis, and compare the results with the OLS specification.

Table 11: Percentage of population who has positive Medical Expenditures

\begin{tabular}{|c|c|c|}
\hline & Obs. & Percent \\
\hline Total Medicare Expenditures & 77,775 & $81.28 \%$ \\
\hline Total Health Expenditures & 92,310 & $97.94 \%$ \\
\hline Out of Pocket Expenditures & 91,255 & $96.85 \%$ \\
\hline Full Sample & 93,911 & \\
\hline
\end{tabular}

In the Two-Part model, there are two separate equations, first we estimate the probability to have positive health expenditures $\operatorname{Pr}\left(Y_{i t} \succ 0\right)$, and then a specification that estimates the level of expenditures, conditional on those being positive $E\left(\ln Y_{i t} \mid Y_{i t} \succ 0\right)$. Usually, the first equation will use a Probit specification to estimate the dichotomous event of having zero or positive expenses (although it could also be a logit), and where the second equation is a linear model on the log scale for positive expenditures.

We investigate the effect of health insurance coverage and working decisions on individuals' total health expenditures, total Medicare expenditures, and out of pocket health expenditures by running the following two separate specifications, equation (2) is used in the first stage of the two-part model, and equation (3) is used in the second stage:

$$
\begin{aligned}
\operatorname{Pr}\left(Y_{i t} \succ\right. & 0)=\beta+\beta_{1} W_{i t}+\beta_{2} E P C H I_{-} R_{i t}+\beta_{3} E P C H I_{-} S_{i t} \\
& +\beta_{4} E P R H I_{-} R_{i t}+\beta_{5} E P R H I_{-} S_{i t} \\
& +\beta_{6} E P U H I_{-} R_{i t}+\beta_{7} E P U H I_{-} S_{i t}+\beta_{8} \mathbf{H I}_{i t} \\
& \beta_{9} \mathbf{H}_{i t}+\beta_{10} \mathbf{X}_{i t}+\beta_{11} \mathbf{D R C}_{i}+\beta_{12} \mathbf{T}_{t}+\varepsilon_{i t} \\
\ln \left(Y_{i t} \mid Y_{i t} \succ\right. & 0)=\beta_{0}+\beta_{w} W_{i t}+\beta_{c r} E P C H I_{-} R_{i t}+\beta_{c s} E P C H I_{-} S_{i t} \\
+ & \beta_{r r} E P R H I_{-} R_{i t}+\beta_{r s} E P R H I_{-} S_{i t} \\
+ & \beta_{u r} E P U H I_{-} R_{i t}+\beta_{u s} E P U H I_{-} S_{i t}+\beta_{h i} \mathbf{H I}_{i t} \\
& \beta_{h} \mathbf{H}_{i t}+\beta_{x} \mathbf{X}_{i t}+\beta_{d} \mathbf{D R C}_{i}+\beta_{y} \mathbf{T}_{t}+\varepsilon_{i t}
\end{aligned}
$$

where $Y_{i t}$ is one of the outcomes of interest (e.g., individual total Medicare Expenditures, individual total health expenditures, and individual out of pocket costs) for individual $i$ in year $t$, while the dependent variables $\ln Y_{i t}$ is the natural logarithm of one of the outcomes of interest for individual $i$ in year $t$. The main explanatory variables of interest is $W_{i t}$, a dummy variable that captures work status (currently 
working at a job=1, not working at a job=0); $E P C H I_{-} R_{i t}{ }^{25}$, which refers to an individual who is covered by health insurance through his/her current employer at time $t$; $E P C H I_{-} S_{i t}$ is a dummy variable, which refers to individual $i$ who is covered by health insurance at time $t$ through his/her spouse's ${ }^{26}$ current employer regardless of his/her own working condition ${ }^{27}$; similarly, EPRHI_R $R_{i t}$ and EPRHI_S $S_{i t}$ refer to retiree health insurance; $E P U H I_{-} R_{i t}$ and $E P U H I_{-} S_{i t}$ is other employer provided health insurance; $\mathbf{H I}_{i t}$ is a list of dummy variables that capture individuals' HI coverage besides EPHI, which include Medicare HMO, private HMO, Medigap, Medicaid as well as other public health insurance programs; $\mathbf{H}_{i t}$ is a list of health controls ${ }^{28} ; \mathbf{X}_{i t}$ is a list of demographic controls-e.g., gender, race, household level income, marital status, education, number of kids etc.; $\mathbf{D R C} \mathbf{C}_{i}$ are dummies that capture individuals' DRC and FRA as described in section 5.6; $\mathbf{T}_{t}$ are year dummies and $\varepsilon_{i t}$ is an unobservable component. Given this set of variables, the base group in the estimation include those who are not working, who only have original Medicare coverage(either Part A, Part B or both), whose annual household income is less than 5,000 dollars (in 2009 dollar), who are never married, who are white, and with high school degree, and those who are not affected by both DRC and FRA (those who are born in 1924 and before), and whose health status is excellent or very good.

\subsection{Results}

Table 12 and Table 13 present the results using the Two-Part model for Medicare Expenditures (column 1), total Health Expenditures (column 2), and out-of-pocket expenditures (column 3). Table 12 is the result from the first stage, the probit specification. As it is customary, we report marginal effects rather than the estimated coefficients. Table 13 shows the regression result from the second stage of the twopart model, which is equivalent to running OLS on the set of individuals with positive expenditures.

\footnotetext{
${ }^{25}$ In MCBS, when individuals are covered by EPCHI, then a follow up question will ask which industry they are working for. We can imagine a situation in which maybe the choice of industry by individuals could be correlated with unobservables, which leads to lower Medicare Expenditures, and if the measure of industry is correlated with work in an insured job, the result could be a biased coefficient on the insurance indicator. But in the estimation of the expanded model, with industry controls, the coefficients of EPCHI_R $R_{i t}$ and $E P C H I_{-} S_{i t}$ become even more negative and statistically significant (so our original specification remains a lower bound on the true effect), so the role of EPCHI seems to not be affected by the inclusion of the industry measures. Given that industry indicators are only available in a few years of the estimation data, we are not including them in our preferred specifications.

${ }^{26}$ Very few people get through father, mother or other people.

${ }^{27}$ There are weighted $1.14 \%$ observations in estimation sample who have health insurance coverage through spouse's current employer. $34.2 \%$ of those are working and the rest $55.8 \%$ are not working.

${ }^{28}$ We follow Fang et.al(2008) and include health reported health status; ever smoker; current smoker; diagnoses of arthritis, high blood pressure, diabetes, cancer, lung disease, heart attack, chronic heart problems, stroke, psychiatric illness, Alzheimer's disease, broken hip; treatment of cataract surgery or a hearing aid; we also include ADLs and IADLs.
} 
Table 12: Marginal Effects of Working and HI coverage on Medical Spending: First Stage

\begin{tabular}{|c|c|c|c|}
\hline Variables & $\begin{array}{l}\text { Medicare Exp. } \\
(1)\end{array}$ & $\begin{array}{l}\text { Total Health Exp. } \\
(2)\end{array}$ & $\begin{array}{l}\text { Out of Pocket Exp. } \\
(3)\end{array}$ \\
\hline Working & $\begin{array}{l}-0.047^{* * *} \\
(0.004)\end{array}$ & $\begin{array}{l}0.001 \\
(0.002)\end{array}$ & $\begin{array}{l}0 \\
(0.002)\end{array}$ \\
\hline EPCHI_R & $\begin{array}{l}-0.053^{* * *} \\
(0.011)\end{array}$ & $\begin{array}{l}0.022^{* * *} \\
(0.004)\end{array}$ & $\begin{array}{l}0.032^{* * *} \\
(0.006)\end{array}$ \\
\hline EPCHI_S & $\begin{array}{l}-0.059^{* * *} \\
(0.014)\end{array}$ & $\begin{array}{l}0.027^{* * *} \\
(0.005)\end{array}$ & $\begin{array}{l}0.034^{* * *} \\
(0.007)\end{array}$ \\
\hline EPRHI_R & $\begin{array}{l}0.147^{* * *} \\
(0.007)\end{array}$ & $\begin{array}{l}0.034^{* * *} \\
(0.002)\end{array}$ & $\begin{array}{l}0.043^{* * *} \\
(0.003)\end{array}$ \\
\hline EPRHI_S & $\begin{array}{l}0.197^{* * *} \\
(0.01)\end{array}$ & $\begin{array}{l}0.036^{* * *} \\
(0.004)\end{array}$ & $\begin{array}{l}0.044^{* * *} \\
(0.005)\end{array}$ \\
\hline EPUHI_R & $\begin{array}{l}0.104^{* * *} \\
(0.01)\end{array}$ & $\begin{array}{l}0.033^{* * *} \\
(0.004)\end{array}$ & $\begin{array}{l}0.041^{* * *} \\
(0.005)\end{array}$ \\
\hline EPUHI_S & $\begin{array}{l}0.203^{* * *} \\
(0.036)\end{array}$ & $\begin{array}{l}0 \\
(.)\end{array}$ & $\begin{array}{l}0 \\
(.)\end{array}$ \\
\hline HMO & $\begin{array}{l}-0.135^{* * *} \\
(0.007)\end{array}$ & $\begin{array}{l}0.025^{* * *} \\
(0.002)\end{array}$ & $\begin{array}{l}0.033^{* * *} \\
(0.003)\end{array}$ \\
\hline HMO_Other & $\begin{array}{l}-0.090^{* * *} \\
(0.007)\end{array}$ & $\begin{array}{l}0.029^{* * *} \\
(0.003)\end{array}$ & $\begin{array}{l}0.031^{* * *} \\
(0.003)\end{array}$ \\
\hline PriHMO & $\begin{array}{l}0.032^{* * *} \\
(0.008)\end{array}$ & $\begin{array}{l}0.028^{* * *} \\
(0.003)\end{array}$ & $\begin{array}{l}0.033^{* * *} \\
(0.004)\end{array}$ \\
\hline Medigap & $\begin{array}{l}0.242^{* * *} \\
(0.007)\end{array}$ & $\begin{array}{l}0.030^{* * * *} \\
(0.002)\end{array}$ & $\begin{array}{l}0.036^{* * *} \\
(0.003)\end{array}$ \\
\hline Medicaid & $\begin{array}{l}0.177^{* * *} \\
(0.009)\end{array}$ & $\begin{array}{l}0.017^{* * * *} \\
(0.002)\end{array}$ & $\begin{array}{l}-0.006^{*} \\
(0.003)\end{array}$ \\
\hline Other_HI & $\begin{array}{l}0.159^{* * *} \\
(0.015)\end{array}$ & $\begin{array}{l}0.026^{* * *} \\
(0.006)\end{array}$ & $\begin{array}{l}0.035^{* * *} \\
(0.007)\end{array}$ \\
\hline DRC35 & $\begin{array}{l}-0.003 \\
(0.006)\end{array}$ & $\begin{array}{l}0.004 \\
(0.003)\end{array}$ & $\begin{array}{l}0.002 \\
(0.003)\end{array}$ \\
\hline DRC40 & $\begin{array}{l}-0.018^{* *} \\
(0.006)\end{array}$ & $\begin{array}{l}0 \\
(0.003)\end{array}$ & $\begin{array}{l}-0.003 \\
(0.003)\end{array}$ \\
\hline DRC45 & $\begin{array}{l}-0.006 \\
(0.006)\end{array}$ & $\begin{array}{l}-0.004 \\
(0.002)\end{array}$ & $\begin{array}{l}-0.002 \\
(0.003)\end{array}$ \\
\hline DRC50 & $\begin{array}{l}-0.011 \\
(0.006)\end{array}$ & $\begin{array}{l}-0.002 \\
(0.002)\end{array}$ & $\begin{array}{l}0.002 \\
(0.003)\end{array}$ \\
\hline DRC55 & $\begin{array}{l}-0.031^{* * *} \\
(0.006)\end{array}$ & $\begin{array}{l}-0.009^{* * *} \\
(0.002)\end{array}$ & $\begin{array}{c}-0.006^{*} \\
(0.003)\end{array}$ \\
\hline DRC60 & $\begin{array}{l}-0.042^{* * *} \\
(0.007)\end{array}$ & $\begin{array}{l}-0.012^{* * *} \\
(0.002)\end{array}$ & $\begin{array}{l}-0.009^{* *} \\
(0.003)\end{array}$ \\
\hline DRC65 & $-0.060 * * *$ & $-0.015^{* * *}$ & $-0.013^{* * *}$ \\
\hline
\end{tabular}

Continued on Next Page... 
Table 12 - Continued

\begin{tabular}{llll}
\hline \hline Variables & \multicolumn{1}{c}{$\begin{array}{c}\text { Medicare Exp. } \\
(1)\end{array}$} & \multicolumn{1}{c}{$\begin{array}{c}\text { Total Health Exp. } \\
(2)\end{array}$} & \multicolumn{1}{c}{$\begin{array}{c}\text { Out of Pocket Exp. } \\
(3)\end{array}$} \\
\hline & $(0.009)$ & $(0.003)$ & $(0.004)$ \\
DRC65_FRA2 & $-0.059^{* * *}$ & $-0.017^{* * *}$ & $-0.018^{* * *}$ \\
& $(0.01)$ & $(0.003)$ & $(0.004)$ \\
DRC70_FRA4 & $-0.093^{* * *}$ & $-0.016^{* * *}$ & $-0.015^{* * *}$ \\
& $(0.011)$ & $(0.004)$ & $(0.005)$ \\
DRC70_FRA6 & $-0.114^{* * *}$ & $-0.016^{* * *}$ & $-0.017^{* * *}$ \\
& $(0.011)$ & $(0.004)$ & $(0.005)$ \\
DRC75_FRA8 & $-0.113^{* * *}$ & $-0.022^{* * *}$ & $-0.022^{* * *}$ \\
& $(0.013)$ & $(0.004)$ & $(0.005)$ \\
DRC75_FRA10 & $-0.142^{* * *}$ & $-0.018^{* * *}$ & $-0.018^{* *}$ \\
& $(0.015)$ & $(0.005)$ & $(0.006)$ \\
DRC80_FRA66 & $-0.217^{* * *}$ & $-0.031^{* * *}$ & $-0.035^{* * *}$ \\
& $(0.011)$ & $(0.004)$ & $(0.005)$ \\
Year Dummy & Yes & Yes & Yes \\
N & 93,909 & 93,735 & 93,735 \\
\hline \hline Note. Robust Standard errors clustered at the individual level are in parentheses. \\
* Significant ta 10 percent. \\
** Significant at 5 percent. \\
*** Significant at 1 percent. \\
\hline \hline
\end{tabular}

\subsubsection{Medicare as secondary payer versus primary payer}

Given the definitions of the variables discussed in the previous subsection, Medicare will be a secondary payer only when the individual is covered through his/her current employer or the current employer of a spouse of any age, which is captured by the variables EPCHI_R and EPCHI_S. The signs of EPCHI_R and EPCHI_S are negative and significantly correlated with Medicare expenditures, compared with the case in which Medicare is primary payer, including retiree HI or union or other health insurance, then the sign is positive and is also significantly correlated with Medicare. This supports the idea that Medicare as secondary or primary payer matters to Medicare expenditures. And we also able to see that the savings to Medicare costs from Medicare as a second payer are significant, those who have health insurance through their spouses' current employer generate $35.2 \%$ less Medicare expenditures compared with those don't have covered though spouses' current employer. Further, among workers, those who have health insurance through his/her current employer generate $26.4 \%$ less Medicare expenditures compared with those who do not have health insurance through their own employer.

However, regardless whether Medicare is secondary or primary payer, all health insurance regressors are positive and significantly correlated to Total Health Expenditures. This suggests that those covered by EPCHI are generating less to the Medicare 
system, but not necessarily their total health expenditures are lower, it is the matter who pays the bills, and the burden of Medicare system is lower for this group and carried mostly by the private sector, and other government health insurance programs in some cases.

Table 13: Working and HI coverage on Medical Spending: Two Part Model

\begin{tabular}{|c|c|c|c|}
\hline Variables & $\begin{array}{c}\text { Medicare Exp. } \\
(1)\end{array}$ & $\begin{array}{l}\text { Total Health Exp. } \\
(2)\end{array}$ & $\begin{array}{l}\text { Out of Pocket Exp. } \\
(3)\end{array}$ \\
\hline Working & $\begin{array}{l}-0.159^{* * *} \\
(7.00)\end{array}$ & $\begin{array}{l}-0.09 * * * \\
(5.99)\end{array}$ & $\begin{array}{c}-0.002 \\
(0.16)\end{array}$ \\
\hline EPCHI_R & $\begin{array}{l}-0.264^{* * *} \\
(3.22)\end{array}$ & $\begin{array}{l}0.527 * * * \\
(11.75)\end{array}$ & $\begin{array}{l}-0.302^{* * *} \\
(7.23)\end{array}$ \\
\hline EPCHI_S & $\begin{array}{l}-0.352^{* * *} \\
(3.36)\end{array}$ & $\begin{array}{l}0.383^{* * *} \\
(6.26)\end{array}$ & $\begin{array}{l}-0.481^{* * *} \\
(8.26)\end{array}$ \\
\hline EPRHI_R & $\begin{array}{l}0.399^{* * *} \\
(10.41)\end{array}$ & $\begin{array}{l}0.612^{* * *} \\
(22.89)\end{array}$ & $\begin{array}{l}-0.349^{* * *} \\
(14.80)\end{array}$ \\
\hline EPRHI_S & $\begin{array}{l}0.454^{* * *} \\
(10.19)\end{array}$ & $\begin{array}{l}0.656^{* * *} \\
(20.84)\end{array}$ & $\begin{array}{l}-0.406^{* * *} \\
(14.08)\end{array}$ \\
\hline EPUHI_R & $\begin{array}{l}0.34^{* * *} \\
(7.19)\end{array}$ & $\begin{array}{l}0.609^{* * *} \\
(18.51)\end{array}$ & $\begin{array}{l}-0.43^{* * *} \\
(14.18)\end{array}$ \\
\hline EPUHI_S & $\begin{array}{l}0.709^{* * *} \\
(5.25)\end{array}$ & $\begin{array}{l}0.783^{* * *} \\
(8.44)\end{array}$ & $\begin{array}{l}-0.215^{* * *} \\
(2.60)\end{array}$ \\
\hline HMO & $\begin{array}{l}-0.638^{* * *} \\
(14.61)\end{array}$ & $\begin{array}{l}-0.008 \\
(0.3)\end{array}$ & $\begin{array}{l}-0.542^{* * *} \\
(21.36)\end{array}$ \\
\hline HMO_Other & $\begin{array}{l}-0.2^{* * *} \\
(4.26)\end{array}$ & $\begin{array}{l}0.222^{* * *} \\
(7.23)\end{array}$ & $\begin{array}{l}-0.674^{* * *} \\
(22.41)\end{array}$ \\
\hline PriHMO & $\begin{array}{l}0.301^{* * *} \\
(6.15)\end{array}$ & $\begin{array}{l}0.439^{* * *} \\
(13.39)\end{array}$ & $\begin{array}{l}-0.434^{* * *} \\
(14.42)\end{array}$ \\
\hline Medigap & $\begin{array}{l}0.571^{* * *} \\
(15.10)\end{array}$ & $\begin{array}{l}0.59 * * * \\
(22.10)\end{array}$ & $\begin{array}{l}-0.093^{* * *} \\
(3.97)\end{array}$ \\
\hline Medicaid & $\begin{array}{l}0.622^{* * *} \\
(14.02)\end{array}$ & $\begin{array}{l}0.523^{* * *} \\
(15.97)\end{array}$ & $\begin{array}{l}-1.347^{* * *} \\
(39.02)\end{array}$ \\
\hline Other_HI & $\begin{array}{l}0.487^{* * *} \\
(6.29)\end{array}$ & $\begin{array}{l}0.553^{* * *} \\
(9.99)\end{array}$ & $\begin{array}{l}-0.009 \\
(0.19)\end{array}$ \\
\hline DRC3.5 & $\begin{array}{l}-0.031 \\
(1.19)\end{array}$ & $\begin{array}{l}0.009 \\
(0.47)\end{array}$ & $\begin{array}{l}0.048^{* * *} \\
(2.61)\end{array}$ \\
\hline DRC4.0 & $\begin{array}{c}-0.033 \\
(1.26)\end{array}$ & $\begin{array}{l}0.015 \\
(0.81)\end{array}$ & $\begin{array}{l}0.035 \\
(1.92)\end{array}$ \\
\hline DRC4.5 & $\begin{array}{l}-0.059^{* *} \\
(2.18)^{*}\end{array}$ & $\begin{array}{l}0.032 \\
(1.75)\end{array}$ & $\begin{array}{l}0.035 \\
(1.92)\end{array}$ \\
\hline DRC5.0 & $\begin{array}{l}-0.079^{* * *} \\
(2.84)\end{array}$ & $\begin{array}{l}0.005 \\
-0.26\end{array}$ & $\begin{array}{l}0.006 \\
(0.29)\end{array}$ \\
\hline
\end{tabular}

Continued on Next Page... 
Table 13 - Continued

\begin{tabular}{llll}
\hline \hline Variables & \multicolumn{1}{c}{$\begin{array}{c}\text { Medicare Exp. } \\
(1)\end{array}$} & \multicolumn{1}{c}{ Total Health Exp. } \\
& \multicolumn{1}{c}{$(2)$} & \multicolumn{1}{c}{$\begin{array}{c}\text { Out of Pocket Exp. } \\
(3)\end{array}$} \\
\hline DRC5.5 & $-0.132^{* * *}$ & $-0.058^{* * *}$ & -0.005 \\
& $(4.59)$ & $(2.92)$ & $(0.25)$ \\
DRC6.0 & $-0.202^{* * *}$ & $-0.116^{* * *}$ & -0.033 \\
& $(6.82)$ & $(5.40)$ & $(1.54)$ \\
DRC6.5 & $-0.225^{* * *}$ & $-0.159^{* * *}$ & -0.05 \\
& $(5.41)$ & $(5.36)$ & $(1.69)$ \\
DRC6.5_FRA2 & $-0.222^{* * *}$ & $-0.103^{* * *}$ & -0.01 \\
& $(4.99)$ & $(3.44)$ & $(0.32)$ \\
DRC7.0_FRA4 & $-0.251^{* * *}$ & $-0.209^{* * *}$ & $-0.081^{* *}$ \\
& $(5.13)$ & $(5.82)$ & $(2.39)^{*}$ \\
DRC7.0_FRRA6 & $-0.219^{* * *}$ & $-0.184^{* * *}$ & $-0.093^{* *}$ \\
& $(4.01)$ & $(4.77)$ & $(2.50)^{*}$ \\
DRC7.5_FRA8 & $-0.305^{* * *}$ & $-0.188^{* * *}$ & -0.073 \\
& $(5.52)$ & $(4.81)$ & $(1.81)$ \\
DRC7.5_FRA10 & $-0.403^{* * *}$ & $-0.336^{* * *}$ & $-0.164^{* * *}$ \\
& $(6.01)$ & $(6.77)$ & $(3.35)$ \\
DRC8.0_FRA66 & $-0.516^{* * *}$ & $-0.472^{* * *}$ & $-0.291^{* * *}$ \\
& $(8.76)$ & $(10.99)$ & $(6.94)$ \\
Year Dummy & Yes & Yes & Yes \\
N & 93,909 & 93,735 & 93,735 \\
\hline \hline Note. T-statistics are in parentheses. & & \\
** Significant at 10 percent. & & \\
*** Significant at 1 percent. & & & \\
\hline \hline & & & \\
\hline
\end{tabular}

\subsubsection{Out of Pocket minimizers}

When estimating the specification that has out of pocket expenditures as the dependent variable, we can observe that health insurance dummies are significant and negatively correlated with this type of expenditure, which suggests that no matter what health insurance coverage an individual chose to enroll in, they are trying to minimize their out of pocket expenditures, which is what we would expect since it is what really matters to individuals.

\subsubsection{Cohorts Effects}

Conditional on working status and health insurance coverage, the negative and significant correlation between the DRC/FRA dummies and the total health expenditures can be interpreted as evidence of cohort effects. The negative effects might be due, for example, to those cohorts taking better care of themselves, having more health 
investment during their lifetimes. And the cohort effects are stronger on Medicare expenditures compared with total health expenditures as well as OOP spending, as the coefficients are largest on Medicare expenditures.

\subsubsection{About Medicare HMO}

From Table 13, we can see that individuals who choose to enroll in Medicare HMO instead of the original Medicare are generating comparatively less costs to the Medicare system. In this paper, Medicare HMO refers to individuals who have only Medicare HMO coverage, and Medicare HMO + Other HI refers to individuals who have access to one of the following health insurance coverage: Medicaid or other public health insurance besides Medicare HMO coverage.

Notice that the original Medicare is the traditional fee-for-service program offered directly through the Federal government, who pays directly for the health care services you receive. In contrast, Medicare HMO plans are paid a fixed amount to provide Medicare benefits. With the original Medicare, individuals generally pay 20 percent coinsurance for doctors' visits and other medical services and enrollees can purchase a Medigap plan that supplements the costs of original Medicare benefits. Medicare HMO enrollees can't use and can't be sold a Medigap plan ${ }^{29}$, they usually pay a fixed amount for services (copayment) and HMO copays cannot be higher than Original Medicare for some services, like chemotherapy, dialysis and durable medical equipment, but could be higher for other services, such as home health and hospital. Also, unlike Original Medicare, HMOs must have a cap on out-of-pocket costs to protect enrollees against very high costs if they receive expensive care ${ }^{30}$. In terms of coverage, most Medicare Advantage plans include prescription drug coverage (MAPDs), while for original Medicare, Part D is not included. HMOs usually only cover care from doctors and hospitals in their network, except in the case of emergency or urgent care and usually requires enrollees to receive a referral from their primary care physician before they can get care from a specialist. Original Medicare will cover care from most doctors and hospitals in the country and don't require a referral. In terms of premiums, on top of Part B premium, individual with original Medicare plus Medigap as well as Part D coverage pay an average Medigap monthly premiums is $\$ 183$, and the Part D base beneficiary premium is $\$ 31.94$. While the premium for MA-PDs through HMOs is only $\$ 40.11$ per month ${ }^{31}$.

So if an individual is generally healthy and only sees doctors and other providers in the HMO's network, his/her out-of-pocket costs may be lower than in Original Medicare. So those Medicare HMO and Medicare HMO + other HI enrollees generates less to Medicare system compared with original Medicare enrollees are due to the differences in policy regulations and those in HMOs are generally healthy individuals that minimize their OOP. Notice the negative and significant effect of Medicare HMO on out of pocket expenditures. These results are interesting on their own, and we interpret them as showing that individuals are navigating quite impressively the maze

\footnotetext{
${ }^{29}$ See CMS(2015).

${ }^{30}$ The maximum out-of-pocket cost for most HMOs in 2015 is $\$ 6,700$.

${ }^{31}$ See Kaiser (2013) (2015), CMS(2009)
} 
of choices and programs available to them, with an implied considerable effort of introspection to choose plans according to their needs.

In Appendix B, Table B.1. we show the results of the OLS specifications including all the observations with zeros expenditures. As expected the key results are quite different, with the key coefficients becoming much larger in absolute value (much more negative) since those with health care coverage from current (or spouse's) employers are much more likely to have zero expenditures, especially Medicare Expenditures.

\section{Medicare savings}

\subsection{Medicare Savings from primary vs. secondary payer}

Given the results presented in Table 13, in which the coefficients on the variables indicating whether individuals are covered with employer provided health insurance through their own work or their spouses (EPCHI_R and EPCHI_S) are negative and statistically significant in the estimation of Medicare Expenditures, we can quantify the yearly Medicare savings resulting from the fact that Medicare is a secondary payer for individuals covered by those types of insurance. The savings linked to this effect come from two sources. On the one hand, health coverage by a primary payer that is not Medicare might actually increase the probability that the recorded Medicare expenditures are zero, which should appear as a negative effect on the probability of observing positive expenditures in the first stage of the Two Part Model specification. Second, for those with a positive amount of Medicare Expenditures, we might observe a decline in the average expenditures.

In order to accomplish this we first estimate the following Two Part Model specification, in which we do not keep track of whether the employer provided insurance comes from the individual's employer or a spouse, and create the variable $E P C H I_{i t}$, which is a dummy that takes the value one when the individuals has an alternative primary payer of health expenditures:

$$
\begin{gathered}
\operatorname{Pr}\left(Y_{i t} \succ 0\right)=\beta+\beta_{1} W_{i t}+\beta_{2} E P C H I_{i t}+\beta_{3} \mathbf{H}_{i t}+\beta_{4} \mathbf{X}_{i t}+\beta_{5} \mathbf{T}_{t}+\varepsilon_{i t} \\
\ln \left(Y_{i t} \mid Y_{i t} \succ 0\right)=\beta_{0}+\beta_{w} W_{i t}+\beta_{c} E P C H I_{i t}+\beta_{h} \mathbf{H}_{i t}+\beta_{x} \mathbf{X}_{i t}+\beta_{y} \mathbf{T}_{t}+\varepsilon_{i t}
\end{gathered}
$$

Table 14 shows the marginal effects from the first stage of Two-part model, the probit specification. From the marginal effect of EPCHI as well as the predicted average probability of having positive Medicare expenditures, which is $82.1 \%$, from first stage of the Two Part Model we find that the EPCHI variable decreases the average probability of observing a positive Medicare Expenditure by around $20.58 \%$. As we can see from Table 15, the coefficient of EPCHI is also negative and statistically significant, and we find that those who are covered by EPCHI and with Medicare as secondary payer, spend on average, $63.5 \%$ less compared with those with Medicare as primary payer. In order to go from these results to a dollar effect, we have to compute 
the average Medicare Expenditure per year in the estimation sample for those with positive Medicare Expenditure, and that is $\$ 7,194^{32}$. Therefore, on average, those who with Medicare as secondary payer spend $\$ 4,568$ less per year per person.

Table 14: Marginal Effects of Medicare savings from Medicare as Secondary Payer: First Stage

\begin{tabular}{|c|c|c|c|}
\hline Variables & $\begin{array}{l}\text { Medicare Exp. } \\
(1)\end{array}$ & $\begin{array}{l}\text { Total Health Exp. } \\
(2)\end{array}$ & $\begin{array}{l}\text { Out of Pocket Exp. } \\
(3)\end{array}$ \\
\hline Working & $\begin{array}{l}-0.061^{* * *} \\
(0.005)\end{array}$ & $\begin{array}{l}0.00 \\
(0.002)\end{array}$ & $\begin{array}{l}-0.001 \\
(0.002)\end{array}$ \\
\hline EPCHI & $\begin{array}{l}-0.169^{* * *} \\
(0.009)\end{array}$ & $\begin{array}{l}0.00 \\
(0.003)\end{array}$ & $\begin{array}{l}0.002 \\
(0.004)\end{array}$ \\
\hline Good Health & $\begin{array}{l}0.020^{* * *} \\
(0.004)\end{array}$ & $\begin{array}{l}0.007^{* * *} * \\
(0.001)\end{array}$ & $\begin{array}{l}0.010^{* * *} \\
(0.002)\end{array}$ \\
\hline Fair Health & $\begin{array}{l}0.037^{* * *} \\
(0.005)\end{array}$ & $\begin{array}{l}0.011^{* * *} \\
(0.002)\end{array}$ & $\begin{array}{l}0.010^{* * *} \\
(0.002)\end{array}$ \\
\hline Poor Health & $\begin{array}{l}0.038^{* * *} \\
(0.009)\end{array}$ & $\begin{array}{l}0.007 \\
(0.005)\end{array}$ & $\begin{array}{l}0.003 \\
(0.004)\end{array}$ \\
\hline Male & $\begin{array}{l}-0.039^{* * *} \\
(0.004)\end{array}$ & $\begin{array}{l}-0.012^{* * *} \\
(0.001)\end{array}$ & $\begin{array}{l}-0.015^{* * *} \\
(0.002)\end{array}$ \\
\hline Age & $\begin{array}{l}0.018^{* * *} \\
(0.002)\end{array}$ & $\begin{array}{l}0.004^{* * *} \\
(0.001)\end{array}$ & $\begin{array}{l}0.004^{* * *} \\
(0.001)\end{array}$ \\
\hline $\mathrm{Age}^{2}$ & $\begin{array}{l}-0.000^{* * *} \\
(0)\end{array}$ & $\begin{array}{l}-0.000^{* * *} \\
(0)\end{array}$ & $\begin{array}{l}-0.000^{* * *} \\
(0)\end{array}$ \\
\hline Ever smoke & $\begin{array}{l}0 \\
(0.004)\end{array}$ & $\begin{array}{l}0.001 \\
(0.001)\end{array}$ & $\begin{array}{l}0.003 \\
(0.002)\end{array}$ \\
\hline Smoker & $\begin{array}{l}-0.034^{* * *} \\
(0.006)\end{array}$ & $\begin{array}{l}-0.012^{* * *} \\
(0.002)\end{array}$ & $\begin{array}{l}-0.018^{* * *} \\
(0.002)\end{array}$ \\
\hline Year Dummies & Yes & Yes & Yes \\
\hline Observations & 93,909 & 93,909 & 93,909 \\
\hline
\end{tabular}

\footnotetext{
${ }^{32}$ This is the average for the whole estimation sample who have positive Expenditures, and comes from the last column of Table 6 or last row of Table 9 .
} 
Table 15: Medicare savings: Secondary Payer

\begin{tabular}{|c|c|c|c|}
\hline Variables & $\begin{array}{c}\text { Medicare Exp. } \\
(1)\end{array}$ & $\begin{array}{l}\text { Total Health Exp. } \\
(2)\end{array}$ & $\begin{array}{l}\text { Out of Pocket Exp. } \\
(3)\end{array}$ \\
\hline Working & $\begin{array}{l}-0.171^{* * *} \\
(6.94)\end{array}$ & $\begin{array}{l}-0.124^{* * *} \\
(7.28)\end{array}$ & $\begin{array}{l}0.04^{* * *} \\
(3.36)\end{array}$ \\
\hline EPCHI & $\begin{array}{l}-0.635^{* * *} \\
(10.49)\end{array}$ & $\begin{array}{l}0.014 \\
(0.92)\end{array}$ & $\begin{array}{l}-0.037 \\
(0.89)\end{array}$ \\
\hline Good Health & $\begin{array}{l}0.353^{* * *} \\
(24.24)\end{array}$ & $\begin{array}{l}0.268^{* * *} \\
(26.95)\end{array}$ & $\begin{array}{l}0.169^{* * *} \\
(17.3)\end{array}$ \\
\hline Fair Health & $\begin{array}{l}0.58 * * * \\
(27.9)\end{array}$ & $\begin{array}{l}0.444^{* * *} \\
(30.95)\end{array}$ & $\begin{array}{l}0.213^{* * *} \\
(14.59)\end{array}$ \\
\hline Poor Health & $\begin{array}{l}0.979 * * * \\
(28.69)\end{array}$ & $\begin{array}{l}0.68 * * * \\
(27.66)\end{array}$ & $\begin{array}{l}0.219^{* * *} \\
(8.05)\end{array}$ \\
\hline Male & $\begin{array}{l}0.016 \\
(0.93)\end{array}$ & $\begin{array}{l}-0.038^{* * *} \\
(3.14)\end{array}$ & $\begin{array}{l}-0.154^{* * *} \\
(12.71)\end{array}$ \\
\hline Age & $\begin{array}{l}0.049^{* * *} \\
(6.95)\end{array}$ & $\begin{array}{l}0.054^{* * *} \\
(10.31)\end{array}$ & $\begin{array}{l}0.039^{* * *} \\
(6.89)\end{array}$ \\
\hline $\mathrm{Age}^{2}$ & $\begin{array}{l}-0.000^{* * *} \\
(5.47)\end{array}$ & $\begin{array}{l}-0.000^{* * *} \\
(9.27)\end{array}$ & $\begin{array}{l}-0.000^{* * *} \\
(6.07)\end{array}$ \\
\hline Ever smoke & $\begin{array}{l}0.076^{* * *} \\
(4.92)\end{array}$ & $\begin{array}{l}0.053^{* * *} \\
(4.93)\end{array}$ & $\begin{array}{l}0.022 \\
(1.99)\end{array}$ \\
\hline Smoker & $\begin{array}{l}-0.273^{* * *} \\
(10.05)\end{array}$ & $\begin{array}{l}-0.253^{* * *} \\
(13.5)\end{array}$ & $\begin{array}{l}-0.179 * * * \\
(9.66)\end{array}$ \\
\hline Year Dummies & Yes & Yes & Yes \\
\hline Observations & 93,909 & 93,909 & 93,909 \\
\hline $\begin{array}{l}\text { Note. T-statistics are } \\
* \text { Significant at } 10 \mathrm{pe} \\
* * \text { Significant at } 5 \mathrm{pe} \\
* * * \text { Significant at } 1 \mathrm{p}\end{array}$ & $\begin{array}{l}\text { parentheses. } \\
\text { at. } \\
\text { at. } \\
\text { ent. }\end{array}$ & & \\
\hline
\end{tabular}

The second step in order to compute the total Medicare savings thanks to the fact that for some individuals Medicare is a secondary payer, requires us to calculate the average yearly number of individuals who are covered by EPCHI, and see the breakdown between those with zero Medicare Expenditures and those with positive Medicare Expenditures. Table 16 which shows the weighted population by mutually exclusive health insurance categories in selected years. For example, in 2003, the number of old Americans represented by the estimation sample is around 29.285 millions. While the weighted population of Medicare as secondary payer, captured by the EPCHI definition, is 0.931 millions in 2003, and varies slightly across years. The average population of Medicare as secondary payer in the estimation sample, which covers 12 years is around 0.92 million. We can then look at the percentage of individuals among these 0.92 million who have positive Medicare Expenditures, and 
Table 16: Weighted population by HI category and year: in millions

\begin{tabular}{l|cccccccc}
\hline HI Year & 2003 & 2004 & 2005 & 2006 & 2007 & 2008 & 2009 & 2010 \\
\hline EPCHI_R & 0.606 & 0.595 & 0.684 & 0.695 & 0.639 & 0.633 & 0.605 & 0.867 \\
EPCHI_S & 0.325 & 0.318 & 0.341 & 0.295 & 0.362 & 0.297 & 0.355 & 0.379 \\
EPCHI & $\mathbf{0 . 9 3 1}$ & $\mathbf{0 . 9 1 3}$ & $\mathbf{1 . 0 2 5}$ & $\mathbf{0 . 9 9 0}$ & $\mathbf{1 . 0 0 2}$ & $\mathbf{0 . 9 3 0}$ & $\mathbf{0 . 9 6 0}$ & $\mathbf{1 . 2 4 6}$ \\
\hline EPRHI_R & 7.630 & 7.664 & 7.343 & 8.366 & 8.154 & 8.253 & 8.107 & 8.208 \\
EPRHI_S & 2.354 & 2.093 & 2.152 & 1.209 & 1.168 & 1.188 & 1.313 & 1.234 \\
EPUHI_R & 0.486 & 0.650 & 0.822 & 1.698 & 2.146 & 2.238 & 2.550 & 2.783 \\
EPUHI_S & 0.063 & 0.074 & 0.080 & 0.032 & 0.040 & 0.026 & 0.019 & 0.010 \\
HMO & 2.673 & 2.723 & 2.709 & 3.578 & 4.414 & 5.083 & 5.681 & 5.951 \\
HMO+Oth & 1.110 & 1.193 & 1.423 & 2.475 & 2.625 & 2.849 & 2.875 & 3.028 \\
Pri HMO & 1.937 & 1.896 & 2.038 & 1.031 & 1.098 & 1.360 & 1.496 & 1.422 \\
Medigap & 7.621 & 7.489 & 7.211 & 6.684 & 6.179 & 6.035 & 6.008 & 6.036 \\
Medicaid & 2.322 & 2.245 & 2.187 & 2.069 & 1.900 & 1.764 & 1.764 & 1.889 \\
Other HI & 0.411 & 0.316 & 0.267 & 0.224 & 0.157 & 0.134 & 0.132 & 0.120 \\
Medicare & 1.749 & 1.769 & 1.738 & 1.653 & 1.756 & 1.744 & 1.641 & 1.738 \\
\hline Total & 29.285 & 29.024 & 28.998 & 30.008 & 30.638 & 31.604 & 32.547 & 33.666 \\
\hline Notal
\end{tabular}

Note: Statistics are calculated using cross-section sample weights. Number of observations varies by variable and sample.

we find that it is $48.9 \%$. Given that the EPCHI effect on the probability of observing this event is to reduce the probability by $20.58 \%$, this means that if the EPCHI variable were to have a zero effect on the probability of observing a positive Medicare Expenditure, the breakdown between positive and zero Medicare Expenditures would deliver that the people with positive expenditures would be $61.57 \%$ instead. This means that the EPCHI is responsible for an increase in 12.67 percentage points in the proportion of those who have zero Medicare Expenditures (12.57 percentage points decrease in the probability of observing a positive Medicare Expenditure). With all this information we are ready to compute the aggregate savings from the secondary payer effect.

The 0.92 millions people with Medicare as secondary payer in a given year generate two sets of savings. First, coming from the fact that we now have more individuals with zero Medicare Expenditures the Medicare system saves 838 million dollars, which results from multiplying the average expenditures of $\$ 7,194$ times the 0.92 million individuals time the 12.67 percent who change from the average to zero. Then we have additional savings for those who have positive Medicare Expenditures and see their average reduced due to the secondary payer effect, and those savings are of 2.055 billions (0.92 millions times $\$ 4,568$ per individual, times the $48.9 \%$ who have positive Medicare Expenditures) savings to the Medicare system, which in total add up to 2.89 billions, and represent savings of $0.648 \%$ of the total net outlays of the Medicare program in $2010 .^{33}$

\footnotetext{
${ }^{33}$ The total Net Mandatory Outlays in 2010 were 446.3 billion dollars as shown in CBO (2011).
} 
In Appendix B, Table B.2. we show the results of estimating an OLS specification of the model presented in this subsection. In that case we include the true zeros in the sample when estimating the model instead of separating the equations as in the Two-Part Model. The result is again that the coefficients of interest grow too large in absolute terms, reflecting the need to increase the effect of the EPCHI variable due to the fact that more than half of those with employer provided health insurance have expenditures equal to zero.

In Appendix C, Table C.1. shows the results from the Heckman selection model, and in here the DRC dummies are used as exclusions which only appear in the first stage of the specification to add non-parametric identification to the model. The results indicate the appropriateness of the sample selection correction strategy, however it is hard to make the case that this should be our preferred specification since the process that results in the variety of medical expenditures by individuals is highly random and hard to argue that is the result of choice.

\subsection{Medicare savings: delay enrollment}

From Table 7, we can see that not everyone enrolls in Medicare when they reach age 65. If delay enrollment doesn't affect the Medicare Expenditures once those individuals enroll, meaning that those who enroll late do not generate comparatively higher costs, then those individuals who delayed their Medicare enrollment are generating savings to Medicare system during the years in which they are not enroll. Notice that the definition of delayed enrollment in this paper is based on government's regulation, so if a person enrolls in Medicare beyond the 7 months initial enrollment period, he/she is considered delayed Medicare enrollment. And years of delayed enrollment is obtained using information on individual's Medicare enrollment year/month and his/her birth year/month. If a person enrolls in Medicare between 65 years 4 months and 66 years 3 months, he/she is considered to have delayed Medicare enrollment for a year or less.

Table 17 shows the estimation results after including delay enrollment dummies in the Medicare Expenditures regression, and after conditioning on health status, health insurance, as well as a battery of socio-demographic variables. ${ }^{34}$.

Table 17: Delay Enrollment on Medicare Expenditures

\begin{tabular}{|c|c|c|c|}
\hline Variables & $\begin{array}{c}\text { Medicare Exp. } \\
(1)\end{array}$ & $\begin{array}{l}\text { Total Health Exp. } \\
(2)\end{array}$ & $\begin{array}{l}\text { Out of Pocket Exp. } \\
(3)\end{array}$ \\
\hline Good Health & $\begin{array}{l}0.351^{* * *} \\
(24.07)\end{array}$ & $\begin{array}{l}0.27 * * * \\
(27.07)\end{array}$ & $\begin{array}{l}0.171^{* * *} \\
(17.53)\end{array}$ \\
\hline Fair Health & $\begin{array}{l}0.574^{* * *} \\
(27.62)\end{array}$ & $\begin{array}{l}0.447^{* * *} \\
(31.09)\end{array}$ & $\begin{array}{l}0.213^{* * *} \\
(14.65)\end{array}$ \\
\hline
\end{tabular}

\footnotetext{
${ }^{34}$ We also tried an specification in which we interacted health status and enrollment dummies, but the coefficients were not statistically significant. Also, whether we code health status as a continuous variable or as health dummies, the regression results are not affected
} 


\begin{tabular}{|c|c|c|c|}
\hline Poor Health & $\begin{array}{l}0.966^{* * *} \\
(28.47)\end{array}$ & $\begin{array}{l}0.685^{* * *} \\
(27.93)\end{array}$ & $\begin{array}{l}0.216^{* * *} \\
(7.99)\end{array}$ \\
\hline 10 Years Up & $\begin{array}{l}0.237 \\
(1.62)\end{array}$ & $\begin{array}{l}0.024 \\
(0.21)\end{array}$ & $\begin{array}{l}-0.712^{* * *} \\
(4.57)\end{array}$ \\
\hline 10 Years & $\begin{array}{l}-0.131 \\
(0.36)\end{array}$ & $\begin{array}{c}-0.103 \\
(0.35)\end{array}$ & $\begin{array}{l}-1.138^{* * *} \\
(3.66)\end{array}$ \\
\hline 9 Years & $\begin{array}{l}0.257 \\
(1.04)\end{array}$ & $\begin{array}{l}0.127 \\
(0.69)\end{array}$ & $\begin{array}{l}-0.74^{* * * *} \\
(3.29)\end{array}$ \\
\hline 8 Years & $\begin{array}{l}0.584^{* * *} \\
(3.28)\end{array}$ & $\begin{array}{l}0.307^{* *} \\
(2.30)\end{array}$ & $\begin{array}{l}-0.537^{* * *} \\
(2.74)\end{array}$ \\
\hline 7 Years & $\begin{array}{l}0.04 \\
(0.15)\end{array}$ & $\begin{array}{c}-0.044 \\
(0.33)\end{array}$ & $\begin{array}{l}-0.446^{* * *} \\
(2.80)\end{array}$ \\
\hline 6 Years & $\begin{array}{l}-0.267 \\
(1.3)\end{array}$ & $\begin{array}{l}-0.021 \\
(0.18)\end{array}$ & $\begin{array}{l}-0.541^{* * *} \\
(3.39)\end{array}$ \\
\hline 5 Years & $\begin{array}{l}0.043 \\
(0.33)\end{array}$ & $\begin{array}{c}-0.048 \\
(0.47)\end{array}$ & $\begin{array}{l}-0.242^{* *} \\
(2.24)\end{array}$ \\
\hline 4 Years & $\begin{array}{l}-0.006 \\
(0.05)\end{array}$ & $\begin{array}{l}0.01 \\
(0.1)\end{array}$ & $\begin{array}{l}-0.023 \\
-0.23\end{array}$ \\
\hline 3 Years & $\begin{array}{l}-0.011 \\
(0.11)\end{array}$ & $\begin{array}{l}-0.08 \\
(1.06)\end{array}$ & $\begin{array}{l}-0.222^{* * *} \\
(2.58)\end{array}$ \\
\hline 2 Years & $\begin{array}{l}0.113 \\
(1.36)\end{array}$ & $\begin{array}{l}0.059 \\
(0.98)\end{array}$ & $\begin{array}{l}-0.186^{* * *} \\
(2.92)\end{array}$ \\
\hline 1 Year & $\begin{array}{l}0.032 \\
(0.57)\end{array}$ & $\begin{array}{l}0.011 \\
(0.27)\end{array}$ & $\begin{array}{l}-0.06 \\
(1.34)\end{array}$ \\
\hline Year Dummies & Yes & Yes & Yes \\
\hline Observations & 93,909 & 93,909 & 93,909 \\
\hline
\end{tabular}

The delay enrollment dummies are not statistically significant in the regression of Medicare Expenditures (except for the dummy that indicates a delay of eight years, which we believe has to do with a small numbers problem), but are significant and negatively correlated with out of pocket expenditures. The latter is yet additional evidence that individuals make a variety of decisions regarding Medicare availability with the objective of minimizing out of pocket costs, which should not surprise us too much since from the point of view of the individual, it is the only set of numbers they really care about.

If delay enrollment doesn't affect Medicare Expenditures conditional on health status, we are able to calculate the average Medicare savings from those who delayed their Medicare enrollment in a given year. Notice, however, that while the enrollment delay indicators do not have an effect on Medicare Expenditures, they can have an effect through health, since as people age their health might deteriorate enough to 
offset at least in part, through the increase costs to the system, the savings incurred thanks to the delay in enrollment.

Table 18: Weighted Health status by age and Medicare enrollment

\begin{tabular}{l|cccccccccccc}
\hline Age & 69 & 70 & 71 & 72 & 73 & 74 & 75 & 76 & 77 & 78 & 79 & 80 \\
\hline \hline Initial Enroll & 2.43 & 2.44 & 2.47 & 2.53 & 2.53 & 2.56 & 2.58 & 2.60 & 2.65 & 2.63 & 2.65 & 2.64 \\
\hline Delay Enroll & & & & & & & & & & & & \\
1 Year & 2.45 & 2.50 & 2.53 & 2.55 & 2.70 & 2.66 & 2.54 & 2.58 & 2.48 & 2.61 & 2.68 & 2.75 \\
2 Years & 2.84 & 2.37 & 2.48 & 2.50 & 2.55 & 2.47 & 2.30 & 2.39 & 2.37 & 2.56 & 2.50 & 2.60 \\
3 Years & 2.79 & 2.90 & 2.38 & 2.69 & 2.80 & 2.71 & 2.66 & 2.47 & 2.70 & 2.34 & 2.61 & 2.36 \\
4 Years & 1.98 & 2.15 & 2.78 & 2.81 & 2.81 & 2.41 & 3.03 & 3.02 & 2.59 & 2.27 & 2.59 & 2.06 \\
5 Years & & 3.00 & 3.04 & 1.79 & 2.25 & 1.89 & 2.47 & 2.48 & 2.82 & 3.02 & 3.38 & 3.01 \\
6 Years & & & 2.00 & 2.41 & 3.00 & 2.30 & 2.91 & 2.75 & 2.73 & 2.40 & 2.76 & 2.70 \\
7 Years & & & & 3.00 & 3.87 & 3.89 & 3.59 & 2.82 & 2.81 & 2.96 & 4.01 & 3.73 \\
8 Years & & & & & & 3.00 & 3.00 & 2.47 & 3.19 & 3.40 & 3.37 & 2.95 \\
9 Years & & & & & & 1.50 & 1.50 & 2.63 & 4.00 & 4.25 & 3.58 & 3.67 \\
10 Years & & & & & & & 3.90 & 3.90 & 3.00 & 2.52 & 3.00 & 2.40 \\
\hline
\end{tabular}

Note: Statistics are calculated using cross-section sample weights. Number of observations varies by variable and sample.

Table 18 shows part of the descriptive statistics of mean weighted health status among individuals who delay enrollment and those who do not, conditional on selected age and years. ${ }^{35}$ Compared with those who enroll at the initial enrollment period, the average mean health of those who delay enrollment varies from worse or better than those who don't. Moreover, the weighted mean health among individuals with different delayed enrollment years also don't show an obvious pattern. Together, Table 17 and table 18 suggest that delay enrollment does not affect Medicare Expenditures conditional on health status.

However, we try to account for the possible increases in Medicare Expenditures due to the changes in health among those who delay enrollment by first estimating the following equation, using a continuous health status measure. Only the second stage of the Two-part model is shown, and the results are presented in Table 19.

$$
\ln Y_{i t}=\beta_{0}+\beta_{w} W_{i t}+\beta_{c} E P C H I_{i t}+\beta_{h} \text { Health }_{i t}+\beta_{x} \mathbf{X}_{i t}+\beta_{y} \mathbf{T}_{t}+\varepsilon_{i t}
$$

This equation is similar to equation 3 , the difference is that Health $h_{i t}$ is a continuous $(0=$ excellent, $1=$ very good, $2=$ good. $3=$ fair, $4=$ poor $)$ self reported health status. The result showing that when health deteriorates by one level (for example, from very good to good), then Medicare Expenditures will increase by $26.8 \%$ conditional on health insurance, working status, other health indicators, income effect, year fixed effects as well as demographic controls. Any health change less than one

\footnotetext{
${ }^{35}$ There are observations in the estimation sample that delayed Medicare enrollment for more that 20 years, but only a few.
} 
level, we are using $26.8 \%$ times the corresponding decimal changes as displayed in Table 18.

Table 19: Medicare savings: Two Part Model

\begin{tabular}{|c|c|c|c|}
\hline Variables & $\begin{array}{c}\text { Medicare Exp. } \\
(1)\end{array}$ & $\begin{array}{l}\text { Total Health Exp. } \\
(2)\end{array}$ & $\begin{array}{l}\text { Out of Pocket Exp. } \\
(3)\end{array}$ \\
\hline Continuous Health & $\begin{array}{l}0.268^{* * *} \\
(36.97)\end{array}$ & $\begin{array}{l}0.2^{* * *} \\
(39.77)\end{array}$ & $\begin{array}{l}0.098^{* * *} \\
(19.16)\end{array}$ \\
\hline Age & $\begin{array}{l}0.048^{* * *} \\
(6.67)\end{array}$ & $\begin{array}{l}0.052^{* * *} \\
(9.94)\end{array}$ & $\begin{array}{l}0.037^{* * *} \\
(6.53)\end{array}$ \\
\hline $\operatorname{Age}^{2}$ & $\begin{array}{l}-0.000^{* * *} \\
(5.19)\end{array}$ & $\begin{array}{l}-0.000^{* * *} \\
(8.88)\end{array}$ & $\begin{array}{l}-0.000^{* * *} \\
(5.65)\end{array}$ \\
\hline Year Dummies & Yes & Yes & Yes \\
\hline Observations & 93,909 & 93,909 & 93,909 \\
\hline \multicolumn{4}{|c|}{$\begin{array}{l}\text { Note. T-statistics are in parentheses. } \\
* \text { Significant at } 10 \text { percent. } \\
* * \text { Significant at } 5 \text { percent. } \\
* * * \text { Significant at } 1 \text { percent. }\end{array}$} \\
\hline
\end{tabular}

The way we quantify the average Medicare savings from those who delayed their Medicare enrollment in a given year is in two steps: 1) calculate the marginal savings from one more year's of delayed enrollment; 2) use the results in table 19 as well as the health differentiation in table 18 to adjust the Medicare savings we calculated in the first step.

The details are as follows: imagine a person enrolled in Medicare at age 66 in 1999 and a one year delay in enrollment. So this person generated savings to Medicare from age 65 to 66, and the savings that he generated are the average Medicare Expenditures of those who enroll during initial enrollment period are aged 65 in $1999 .{ }^{36}$ If there are 10 more people like him/her, then the total savings are the average Medicare Expenditures times the number of people. We can call the savings from delayed enrollment from age 65 to $66, S_{1}$.

How about the savings from those who enrolled in Medicare at age 67 in 1999 and delayed enrollment for two years? It should be the sum of the savings from age 65 to 66 and from age 66 to 67 . Since we already calculated the savings from delayed enrollment from age 65 to 66 , and we assume that any future delayed enrollment in Medicare from age 65 to 66 would generate the same amount of savings, which is $S_{1}$. So conditional on $S_{1}$, we only need to calculate the marginal savings from age 66 to 67 for those who enrolled in Medicare at age 67, and that can by obtained by using average Medicare expenditures of those who are age 66 in 1999 times the total

\footnotetext{
${ }^{36}$ Notice that the reason we use the average of those who enroll is because in the previously shown estimates, the enrollment dummies where not statistically different from zero.
} 
weighted population who enrolled in Medicare in 1999 after two years' delay. Similarly, we call it $S_{2}$. So the total savings would be $S_{1}+S_{2}$ for those delayed enrollment for 2 years in a given year. Notice that, given the nature of delay enrollment, there are person who are aged 65 in 1999, and we can have $S_{1}$ up to $S_{20}$ for those who delayed enrollment for 20 years.

Notice that given the nature of delay enrollment, there are some individuals who enroll in Medicare beyond 65 years and 3 months but younger than 66, and are considered as delayed enrollment for a year. For those individuals, their Medicare savings are the population times the average Medicare Expenditures of people who are age 65 . And that part of savings are $S_{0}$.

$S_{0}, S_{1}$ are the Medicare savings from the first step. The way to adjust the Medicare savings counting health differentiation is as follows: suppose a person delayed enrollment for 5 years and he enrolled in Medicare at age 70, and his savings are $\sum_{i=1}^{5} S_{i}$. As shown in table 18 , conditional on age at 70, the average health for individuals who delayed enrollment for 4 year is 2.15 , and that for those who delayed 5 years is 3.00 , so the health difference will be $0.85^{37}$ (which is 3.00-2.15), so the Medicare savings counting on health differentiation for that person will be $\sum_{i=1}^{5} S_{i}(1-(0.85 \times 0.268))=0.772 \sum_{i=1}^{5} S_{i}$.

We do this two step calculation for every subgroup of individuals conditional on years delayed/age/survey year, then we sum across all survey years and take the average, which will be the average Medicare savings from delay enrollment in a given year.

Table 20 is the mean Medicare Expenditures by age from those who enroll in Medicare at initial enrollment period. The average Medicare savings from delay enrollment in a given year resulting from our two step procedure show savings of 333.67 millions, which is about $0.07 \%$ of the Net Mandatory outlays of the Medicare system in 2010.

Now, it is interesting to understand how work and health insurance coverage also comes into play in the costs savings linked with delay enrollment. We have estimated a simple binary model of delay enrollment as a function of our battery of controls and our key working and insurance indicators, and our findings show that working and having health insurance coverage increases the probability of delaying enrollment (which stands at around $4.8 \%$ ) by two thirds, indicating that a sizable part of the savings in Medicare Expenditures thanks to delay enrollment can be traced back to the employment decisions of individuals and the health insurance coverage they have while working.

Finally, we should mention that we are not including in our calculation of savings due to delay enrollment, the fact that some individuals die before even enrolling in Medicare, providing a cost saving silver lining to the government due to their ultimate demise. We have not tried to compute these possible savings due to the fact that to truly tackle the problem we would have to expand our research to compute the savings or costs linked to early death, as well as longer than expected longevity among those

\footnotetext{
${ }^{37}$ For this estimation,we allow health improvement from delaying enrollment.
} 
never enrolled and also among those eventually enrolled. A careful analysis of the effects of mortality on Medicare expenditures is out of the scope of this research piece but part of our future research.

Table 20: Mean Medicare Expenditures by age: initial enrollment

\begin{tabular}{cl|lllll}
\hline \multirow{2}{*}{ Age } & Year & 1999 & 2000 & 2001 & 2002 & 2003 \\
\hline 65 & $\$ 1,127.22$ & $\$ 658.96$ & $\$ 955.66$ & $\$ 2,813.95$ & $\$ 1,138.79$ \\
66 & $\$ 2,190.95$ & $\$ 2,636.48$ & $\$ 3,238.4$ & $\$ 4,088.09$ & $\$ 2,899.92$ \\
67 & $\$ 2,689.05$ & $\$ 3,538.75$ & $\$ 4,258.17$ & $\$ 3,276.54$ & $\$ 3,259.76$ \\
68 & $\$ 2,966.83$ & $\$ 3,182.25$ & $\$ 3,451.66$ & $\$ 4,242.71$ & $\$ 3,818.66$ \\
69 & $\$ 3,408.78$ & $\$ 3,780.4$ & $\$ 5,089.2$ & $\$ 4,636.31$ & $\$ 4,967.78$ \\
70 & $\$ 5,257.63$ & $\$ 4,102.56$ & $\$ 7,048.22$ & $\$ 4,446.47$ & $\$ 4,926.3$ \\
71 & $\$ 3,482.89$ & $\$ 4,146.43$ & $\$ 4,068.41$ & $\$ 5,051.48$ & $\$ 6,326.29$ \\
72 & $\$ 4,097.32$ & $\$ 4,797.84$ & $\$ 4,752.75$ & $\$ 4,867$ & $\$ 6,519.99$ \\
73 & $\$ 4,651.55$ & $\$ 4,342.33$ & $\$ 5,336.81$ & $\$ 6,256.5$ & $\$ 6,397.72$ \\
74 & $\$ 3,689.46$ & $\$ 4,841.84$ & $\$ 5,527.2$ & $\$ 5,850.65$ & $\$ 7,426.65$ \\
75 & $\$ 3,978.21$ & $\$ 4,660.72$ & $\$ 4,997.1$ & $\$ 5,739.95$ & $\$ 6,555.62$ \\
76 & $\$ 4,230.34$ & $\$ 4,941.84$ & $\$ 5,511.61$ & $\$ 6,113.66$ & $\$ 6,815.89$ \\
77 & $\$ 5,818.21$ & $\$ 5,648.32$ & $\$ 6,875.18$ & $\$ 6,055.2$ & $\$ 7,162.31$ \\
78 & $\$ 6,656.33$ & $\$ 6,020.35$ & $\$ 6,972.73$ & $\$ 7,163.03$ & $\$ 6,017.56$ \\
79 & $\$ 4,425.8$ & $\$ 6,126.82$ & $\$ 6,664.19$ & $\$ 6,842.04$ & $\$ 6,115.65$ \\
80 & $\$ 3,513.69$ & $\$ 5,692.68$ & $\$ 7,084.58$ & $\$ 7,940.85$ & $\$ 6,598.48$ \\
\hline \multicolumn{2}{c}{ Medicare Expenditures are calculated using cross-section sample weights from MCBS. Number of } \\
Noter \\
observations varies by variable and sample.
\end{tabular}

\section{Conclusions}

The Medicare savings in a given year from the fact that Medicare is a secondary payer versus first payer for around 0.92 million Americans every year is around 2.89 billion dollars. Additionally, when individuals delay their Medicare enrollment, which is highly correlated with the decision to work and be covered by health insurance, they also generate savings to the Medicare system, which amounts to 333.67 millions in additional savings. Interestingly, our estimates also show that the secondary payer effect is not correlated with total health expenditures, which comes to support the reliability of our results.

The increases in the FRA and DRC are therefore reporting additional savings to the government on top of those considered when the policies were developed. In an interesting twist the reforms are helping the Medicare system reduce its costs while the private insurance sector and other government health insurance programs see their costs increased due to the trends in labor force participation, but of course obtain the counterpart coming from the work of their employees. The Social Security reform 
is improving the Medicare balance through individuals' labor supply and health insurance coverage. So not everything about Medicare Costs is bad news, and we can report that some savings are occurring when more people are working and covered by employer provided health insurance coverage. Clearly any future reform to the Social Security system, health insurance reform or tax reform, and further changes in longevity that will affect labor force participation and/or health insurance coverage, will affect Medicare costs through the channels described in our research.

Notice that our research does not study the possible increase in Medicare Costs due to the increase in the FRA through the effect that this policy is likely having on the number of individuals currently receiving disability benefits. The literature seems to agree that applications and awards in the last decade have likely been increased due to the reforms, but has not provided a quantification of the effects on the Medicare costs structure. The latter is also part of our future research endeavors. 


\section{Appendices}

\section{A More Estimation Results}

More estimations results for Table 12 and table 13 from Two-Part Model are provided below:

Table A.1: Marginal Effects of Working and HI coverage on Medical Spending: First Stage

\begin{tabular}{|c|c|c|c|}
\hline Variables & $\begin{array}{c}\text { Total Medicare } \\
(1)\end{array}$ & $\begin{array}{c}\text { Total Medical } \\
(2)\end{array}$ & $\begin{array}{l}\text { Out of Pocket Exp. } \\
(3)\end{array}$ \\
\hline Male & $\begin{array}{l}-0.032^{* * *} \\
(0.004)\end{array}$ & $\begin{array}{l}-0.009 * * * \\
(0.001)\end{array}$ & $\begin{array}{l}-0.012^{* * *} \\
(0.002)\end{array}$ \\
\hline Income_5k_10k & $\begin{array}{l}0.007 \\
(0.007)\end{array}$ & $\begin{array}{l}0.004 \\
(0.003)\end{array}$ & $\begin{array}{l}-0.001 \\
(0.003)\end{array}$ \\
\hline Income_10k_15k & $\begin{array}{l}0.009 \\
(0.007)\end{array}$ & $\begin{array}{l}0.008 * * \\
(0.003)\end{array}$ & $\begin{array}{l}0.010^{* *} \\
(0.003)\end{array}$ \\
\hline Income_15k_20k & $\begin{array}{l}0.018^{*} \\
(0.008)\end{array}$ & $\begin{array}{l}0.010^{* * *} \\
(0.003)\end{array}$ & $\begin{array}{l}0.011^{* *} \\
(0.003)\end{array}$ \\
\hline Income_20k_25k & $\begin{array}{l}0.022^{* *} \\
(0.008)\end{array}$ & $\begin{array}{l}0.009 * * \\
(0.003)\end{array}$ & $\begin{array}{l}0.011^{* *} \\
(0.004)\end{array}$ \\
\hline Income_25k_30k & $\begin{array}{l}0.024^{* *} \\
(0.008)\end{array}$ & $\begin{array}{l}0.015^{* * *} \\
(0.003)\end{array}$ & $\begin{array}{l}0.019^{* * *} \\
(0.004)\end{array}$ \\
\hline Income_30k_35k & $\begin{array}{l}0.030 * * * \\
(0.009)\end{array}$ & $\begin{array}{l}0.014^{* * *} \\
(0.003)\end{array}$ & $\begin{array}{l}0.017 * * * \\
(0.004)\end{array}$ \\
\hline Income_35k_40k & $\begin{array}{l}0.036^{* * *} \\
(0.01)\end{array}$ & $\begin{array}{l}0.025^{* * *} \\
(0.004)\end{array}$ & $\begin{array}{l}0.030^{* * *} \\
(0.005)\end{array}$ \\
\hline Income_40k_45k & $\begin{array}{l}0.035^{* * *} \\
(0.01)\end{array}$ & $\begin{array}{l}0.023^{* * *} \\
(0.004)\end{array}$ & $\begin{array}{l}0.030^{* * *} \\
(0.005)\end{array}$ \\
\hline Income_45k_50k & $\begin{array}{l}0.019 \\
(0.011)\end{array}$ & $\begin{array}{l}0.018^{* * *} \\
(0.004)\end{array}$ & $\begin{array}{l}0.024^{* * *} \\
(0.006)\end{array}$ \\
\hline Income_50plus & $\begin{array}{l}0.016 \\
(0.009)\end{array}$ & $\begin{array}{l}0.026^{* * *} \\
(0.003)\end{array}$ & $\begin{array}{l}0.031^{* * *} \\
(0.004)\end{array}$ \\
\hline No Schooling & $\begin{array}{l}-0.002 \\
(0.015)\end{array}$ & $\begin{array}{l}-0.008 \\
(0.004)\end{array}$ & $\begin{array}{l}-0.013^{* *} \\
(0.005)\end{array}$ \\
\hline Less than 8th & $\begin{array}{l}-0.005 \\
(0.006)\end{array}$ & $\begin{array}{c}-0.005^{*} \\
(0.002)\end{array}$ & $\begin{array}{l}-0.007^{* *} \\
(0.002)\end{array}$ \\
\hline Some High School & $\begin{array}{l}0 \\
(0.005)\end{array}$ & $\begin{array}{l}-0.003 \\
(0.002)\end{array}$ & $\begin{array}{l}-0.004 \\
(0.002)\end{array}$ \\
\hline Some College & $\begin{array}{l}-0.007 \\
(0.004)\end{array}$ & $\begin{array}{l}0.003 \\
(0.002)\end{array}$ & $\begin{array}{l}0.003 \\
(0.002)\end{array}$ \\
\hline College & 0.004 & $0.006^{*}$ & $0.010^{* * *}$ \\
\hline
\end{tabular}

Continued on Next Page... 
Table A.1 - Continued

\begin{tabular}{|c|c|c|c|}
\hline Variables & $\begin{array}{c}\text { Total Medicare } \\
\text { (1) }\end{array}$ & $\begin{array}{l}\text { Total Medical } \\
\text { (2) }\end{array}$ & $\begin{array}{l}\text { Out of Pocket Exp. } \\
(3)\end{array}$ \\
\hline & $(0.006)$ & $(0.003)$ & $(0.003)$ \\
\hline \multirow{2}{*}{ Graduate School } & 0.01 & $0.009^{* *}$ & $0.014^{* * *}$ \\
\hline & $(0.007)$ & $(0.003)$ & $(0.004)$ \\
\hline \multirow[t]{2}{*}{ Married } & $0.025^{* *}$ & $0.008^{* *}$ & $0.010^{* *}$ \\
\hline & $(0.01)$ & $(0.003)$ & $(0.004)$ \\
\hline \multirow[t]{2}{*}{ Widow } & 0.015 & 0.004 & $0.007^{*}$ \\
\hline & $(0.01)$ & $(0.003)$ & $(0.004)$ \\
\hline \multirow[t]{2}{*}{ Divorced } & 0.005 & 0.006 & 0.007 \\
\hline & $(0.011)$ & $(0.003)$ & $(0.004)$ \\
\hline \multirow[t]{2}{*}{ Separated } & -0.022 & 0.004 & 0.004 \\
\hline & $(0.017)$ & $(0.005)$ & $(0.006)$ \\
\hline \multirow[t]{2}{*}{ Black } & $-0.031^{* * *}$ & $-0.008 * * *$ & $-0.009^{* * *}$ \\
\hline & $(0.006)$ & $(0.002)$ & $(0.002)$ \\
\hline \multirow[t]{2}{*}{ Hispanic } & $-0.039 * * *$ & -0.001 & $-0.019 * * *$ \\
\hline & $(0.01)$ & $(0.004)$ & $(0.003)$ \\
\hline \multirow{2}{*}{ Other Race } & $-0.046^{* * *}$ & -0.006 & $-0.011^{* *}$ \\
\hline & $(0.01)$ & $(0.003)$ & $(0.003)$ \\
\hline \multirow[t]{2}{*}{ Number of Kids } & -0.001 & 0 & 0 \\
\hline & $(0.001)$ & $(0)$ & $(0)$ \\
\hline \multirow[t]{2}{*}{ Good Health } & $0.017^{* * *}$ & $0.006^{* * *}$ & $0.010 * * *$ \\
\hline & $(0.003)$ & $(0.001)$ & $(0.002)$ \\
\hline \multirow{2}{*}{ Fair Health } & $0.035^{* * *}$ & $0.011^{* * *}$ & $0.012^{* * *}$ \\
\hline & $(0.005)$ & $(0.002)$ & $(0.002)$ \\
\hline \multirow[t]{2}{*}{ Poor Health } & $0.031^{* * *}$ & 0.008 & 0.007 \\
\hline & $(0.008)$ & $(0.005)$ & $(0.004)$ \\
\hline \multirow[t]{2}{*}{ Ever Smoke } & 0.004 & 0 & 0.001 \\
\hline & $(0.004)$ & $(0.001)$ & $(0.002)$ \\
\hline \multirow[t]{2}{*}{ Smoker } & $-0.031^{* * *}$ & $-0.010^{* * *}$ & $-0.016^{* * *}$ \\
\hline & $(0.005)$ & $(0.002)$ & $(0.002)$ \\
\hline $\begin{array}{l}\text { Note. Robust Standar } \\
\text { * Significant at } 10 \text { per } \\
\text { ** Significant at } 5 \text { per }\end{array}$ & clustered & vidual level are in & ntheses. \\
\hline
\end{tabular}


Table A.2: Working and HI coverage on Medical Spending: Second Stage

\begin{tabular}{|c|c|c|c|}
\hline Variables & $\begin{array}{c}\text { Total Medicare } \\
(1)\end{array}$ & $\begin{array}{c}\text { Total Medical } \\
(2)\end{array}$ & $\begin{array}{l}\text { Out of Pocket Exp. } \\
(3)\end{array}$ \\
\hline Male & $\begin{array}{l}0.038^{* *} \\
(2.24)\end{array}$ & $\begin{array}{l}-0.017 \\
(1.4)\end{array}$ & $\begin{array}{l}-0.17^{* * * *} \\
(14.44)\end{array}$ \\
\hline Income_5k-10k & $\begin{array}{l}0.025 \\
(0.68)\end{array}$ & $\begin{array}{l}0.039 \\
(1.49)\end{array}$ & $\begin{array}{l}-0.024 \\
(0.85)\end{array}$ \\
\hline Income_10k-15k & $\begin{array}{l}0.114^{* * *} \\
(3.13)\end{array}$ & $\begin{array}{l}0.124^{* * *} \\
(4.65)\end{array}$ & $\begin{array}{l}0.154^{* * *} \\
(5.44)\end{array}$ \\
\hline Income_15k-20k & $\begin{array}{l}0.151^{* * *} \\
(4.02)\end{array}$ & $\begin{array}{l}0.173^{* * *} \\
(6.34)\end{array}$ & $\begin{array}{l}0.236^{* * *} \\
(8.27)\end{array}$ \\
\hline Income_20k-25k & $\begin{array}{l}0.167^{* * *} \\
(4.38)\end{array}$ & $\begin{array}{l}0.217^{* * *} \\
(7.88)\end{array}$ & $\begin{array}{l}0.313^{* * *} \\
(10.89)\end{array}$ \\
\hline Income_25k-30k & $\begin{array}{l}0.158^{* * *} \\
(4.01)\end{array}$ & $\begin{array}{l}0.232 \text { *** } \\
(8.15)\end{array}$ & $\begin{array}{l}0.365^{* * *} \\
(12.37)\end{array}$ \\
\hline Income_30k-35k & $\begin{array}{l}0.166^{* * *} \\
(4.09)\end{array}$ & $\begin{array}{l}0.244^{* * *} \\
(8.36)\end{array}$ & $\begin{array}{l}0.393^{* * *} \\
(12.96)\end{array}$ \\
\hline Income_35k-40k & $\begin{array}{l}0.2^{* * *} \\
(4.68)\end{array}$ & $\begin{array}{l}0.286 \text { *** } \\
(9.37)\end{array}$ & $\begin{array}{l}0.437^{* * *} \\
(13.79)\end{array}$ \\
\hline Income_40k-45k & $\begin{array}{l}0.237^{* * *} \\
(5.37)\end{array}$ & $\begin{array}{l}0.331^{* * *} \\
(10.53)\end{array}$ & $\begin{array}{l}0.469^{* * *} \\
(14.49)\end{array}$ \\
\hline Income_45k-50k & $\begin{array}{l}0.223^{* * *} \\
(4.94)\end{array}$ & $\begin{array}{l}0.325^{* * *} \\
(10.10)\end{array}$ & $\begin{array}{l}0.504^{* * *} \\
(15.25)\end{array}$ \\
\hline Income_50plus & $\begin{array}{l}0.256^{* * *} \\
(6.41)\end{array}$ & $\begin{array}{l}0.364^{* * *} \\
(12.57)\end{array}$ & $\begin{array}{l}0.575^{* * *} \\
(19.07)\end{array}$ \\
\hline No Schooling & $\begin{array}{l}-0.017 \\
(0.25)\end{array}$ & $\begin{array}{l}-0.076 \\
(1.47)\end{array}$ & $\begin{array}{l}-0.381^{* * *} \\
(6.04)\end{array}$ \\
\hline Less than 8th & $\begin{array}{l}-0.075 \\
(2.95)\end{array}$ & $\begin{array}{c}-0.106 \\
(5.86)\end{array}$ & $\begin{array}{l}-0.165 \\
(8.96)\end{array}$ \\
\hline Some High School & $\begin{array}{l}-0.067^{* * *} \\
(3.02)\end{array}$ & $\begin{array}{l}-0.049^{* * *} \\
(3.17)\end{array}$ & $\begin{array}{l}-0.058^{* * *} \\
(3.68)\end{array}$ \\
\hline Some College & $\begin{array}{l}0.057^{* * *} \\
(3.14)\end{array}$ & $\begin{array}{l}0.042^{* * *} \\
(3.34)\end{array}$ & $\begin{array}{l}0.072^{* * *} \\
(5.85)\end{array}$ \\
\hline College & $\begin{array}{l}0.078^{* * *} \\
(3.11)\end{array}$ & $\begin{array}{l}0.095^{* * *} \\
(5.56)\end{array}$ & $\begin{array}{l}0.187^{* * *} \\
(11.30)\end{array}$ \\
\hline Graduate School & $\begin{array}{l}0.107^{* * *} \\
(3.89)\end{array}$ & $\begin{array}{l}0.144^{* * *} \\
(7.67)\end{array}$ & $\begin{array}{l}0.227^{* * *} \\
(11.82)\end{array}$ \\
\hline Married & $\begin{array}{l}0.008 \\
(0.16)\end{array}$ & $\begin{array}{l}0.042 \\
(1.27)\end{array}$ & $\begin{array}{l}0.077^{* *} \\
(2.41)\end{array}$ \\
\hline Widow & $\begin{array}{l}0.044 \\
(0.95)\end{array}$ & $\begin{array}{l}0.067^{* *} \\
(2.01)\end{array}$ & $\begin{array}{l}0.108^{* * *} \\
(3.37)\end{array}$ \\
\hline Divorced & 0.046 & 0.053 & $0.071^{* *}$ \\
\hline
\end{tabular}

Continued on Next Page... 
Table A.2 - Continued

\begin{tabular}{|c|c|c|c|}
\hline Variables & $\begin{array}{c}\text { Total Medicare } \\
(1)\end{array}$ & $\begin{array}{c}\text { Total Medical } \\
\qquad(2)\end{array}$ & $\begin{array}{l}\text { Out of Pocket Exp. } \\
(3)\end{array}$ \\
\hline & $(0.9)$ & $(1.44)$ & $(2.01)$ \\
\hline \multirow[t]{2}{*}{ Separated } & 0.087 & 0.007 & -0.056 \\
\hline & $(0.98)$ & $(0.1)$ & $(0.82)$ \\
\hline \multirow[t]{2}{*}{ Black } & $0.063^{* *}$ & $-0.05 * *$ & $-0.184 * * *$ \\
\hline & $(2.22)$ & $(2.48)$ & $(8.83)$ \\
\hline \multirow[t]{2}{*}{ Hispanic } & -0.042 & $-0.156^{* * *}$ & $-0.359 * * *$ \\
\hline & $(0.79)$ & $(3.93)$ & $(8.13)$ \\
\hline \multirow{2}{*}{ Other Race } & -0.055 & $-0.14^{* * *}$ & $-0.325 * * *$ \\
\hline & $(1.22)$ & $(4.42)$ & $(9.07)$ \\
\hline \multirow[t]{2}{*}{ Number of Kids } & -0.001 & 0.001 & -0.003 \\
\hline & $(0.20)$ & $(0.28)$ & $(0.99)$ \\
\hline \multirow[t]{2}{*}{ Good Health } & $0.349^{* * *}$ & $0.267 * * *$ & $0.171 * * *$ \\
\hline & $(24.75)$ & $(27.72)$ & $(18.19)$ \\
\hline \multirow[t]{2}{*}{ Fair Health } & $0.586^{* * *}$ & $0.449 * * *$ & $0.234^{* * *}$ \\
\hline & $(29.29)$ & $(32.41)$ & $(17.03)$ \\
\hline \multirow[t]{2}{*}{ Poor Health } & $0.974^{* * *}$ & $0.689 * * *$ & $0.26 * * *$ \\
\hline & $(29.61)$ & $(29.03)$ & $(10.11)$ \\
\hline \multirow[t]{2}{*}{ Eversmoke } & $0.081^{* * *}$ & $0.057^{* * *}$ & $0.029^{* * *}$ \\
\hline & $(5.50)$ & $(5.65)$ & $(2.77)$ \\
\hline \multirow[t]{2}{*}{ Smoker } & $-0.263^{* * *}$ & $-0.239^{* * *}$ & $-0.175^{* * *}$ \\
\hline & $(9.96)$ & $(13.20)$ & $(9.93)$ \\
\hline $\mathrm{N}$ & 93,909 & 93,735 & 93,735 \\
\hline $\begin{array}{l}\text { Note. T-statistics are } \\
* \text { Significant at } 10 \text { per } \\
* * \text { Significant at } 5 \text { per } \\
* * * \text { Significant at } 1 \text { pe }\end{array}$ & rentheses. & & \\
\hline
\end{tabular}

\section{B OLS specifications of key results}

Table B.1 shows the OLS regression results of the effects of working and HI coverage on Medical spending, and is comparable to table 13. Similarly, Table B.2 is comparable to table 14. 
Table B.1: Working and HI coverage on Medical Spending: OLS

\begin{tabular}{|c|c|c|c|}
\hline Variables & $\begin{array}{c}\text { Medicare Exp. } \\
(1)\end{array}$ & $\begin{array}{l}\text { Total Health Exp. } \\
(2)\end{array}$ & $\begin{array}{l}\text { Out of Pocket Exp. } \\
(3)\end{array}$ \\
\hline Working & $\begin{array}{l}-0.528^{* * *} \\
(0.043)\end{array}$ & $\begin{array}{l}-0.066^{* *} \\
(0.024)\end{array}$ & $\begin{array}{l}0.002 \\
(0.023)\end{array}$ \\
\hline EPCHI_R & $\begin{array}{l}-0.941^{* * *} \\
(0.141)\end{array}$ & $\begin{array}{l}1.134^{* * *} \\
(0.08)\end{array}$ & $\begin{array}{l}0.308^{* * *} \\
(0.073)\end{array}$ \\
\hline EPCHI_S & $\begin{array}{l}-1.074^{* * *} \\
(0.167)\end{array}$ & $\begin{array}{l}0.946^{* * *} \\
(0.092)\end{array}$ & $\begin{array}{l}0.05 \\
(0.088)\end{array}$ \\
\hline EPRHI_R & $\begin{array}{l}1.688^{* * *} \\
(0.075)\end{array}$ & $\begin{array}{l}1.291^{* * *} \\
(0.054)\end{array}$ & $\begin{array}{l}0.300^{* * *} \\
(-0.049)\end{array}$ \\
\hline EPRHI_S & $\begin{array}{l}2.043^{* * *} \\
(0.085)\end{array}$ & $\begin{array}{l}1.314^{* * *} \\
(0.058)\end{array}$ & $\begin{array}{l}0.221^{* * *} \\
(0.053)\end{array}$ \\
\hline EPUHI_R & $\begin{array}{l}1.337^{* * *} \\
(0.091)\end{array}$ & $\begin{array}{l}1.296^{* * *} \\
(0.06)\end{array}$ & $\begin{array}{l}0.212^{* * *} \\
(0.055)\end{array}$ \\
\hline EPUHI_S & $\begin{array}{l}2.320^{* * *} \\
(0.222)\end{array}$ & $\begin{array}{l}1.505^{* * *} \\
(0.116)\end{array}$ & $\begin{array}{l}0.528^{* * *} \\
(0.108)\end{array}$ \\
\hline $\mathrm{HMO}$ & $\begin{array}{l}-1.695^{* * *} \\
(0.079)\end{array}$ & $\begin{array}{l}0.651^{* * *} \\
(0.055)\end{array}$ & $\begin{array}{l}0.081 \\
(0.051)\end{array}$ \\
\hline HMO_Other & $\begin{array}{l}-0.822^{* * *} \\
(0.09)\end{array}$ & $\begin{array}{l}0.930 * * * \\
(0.05) 8\end{array}$ & $\begin{array}{l}-0.01 \\
(0.054)\end{array}$ \\
\hline PriHMO & $\begin{array}{l}0.568^{* * *} \\
(0.101)\end{array}$ & $\begin{array}{l}1.062^{* * *} \\
(0.061)\end{array}$ & $\begin{array}{l}0.156^{* *} \\
(0.056)\end{array}$ \\
\hline Medigap & $\begin{array}{l}2.321^{* * *} \\
(0.073)\end{array}$ & $\begin{array}{l}1.255^{* * *} \\
(0.054)\end{array}$ & $\begin{array}{l}0.528^{* * *} \\
(0.049)\end{array}$ \\
\hline Medicaid & $\begin{array}{l}2.159 * * * \\
(0.084)\end{array}$ & $\begin{array}{l}1.099 * * * \\
(0.064)\end{array}$ & $\begin{array}{l}-1.052^{* * *} \\
(0.061)\end{array}$ \\
\hline Other_HI & $\begin{array}{l}1.954^{* * *} \\
(0.138)\end{array}$ & $\begin{array}{l}1.227^{* * *} \\
(0.092)\end{array}$ & $\begin{array}{l}0.618^{* * *} \\
(0.082)\end{array}$ \\
\hline Male & $\begin{array}{l}-0.190^{* * *} \\
(0.033)\end{array}$ & $\begin{array}{l}-0.109^{* * *} \\
(0.019)\end{array}$ & $\begin{array}{l}-0.249^{* * *} \\
(0.018)\end{array}$ \\
\hline Income_5k_10k & $\begin{array}{l}0.048 \\
(0.067)\end{array}$ & $\begin{array}{l}0.073 \\
(0.049)\end{array}$ & $\begin{array}{l}-0.036 \\
(0.048)\end{array}$ \\
\hline Income_10k_15k & $\begin{array}{l}0.137^{*} \\
(0.067)\end{array}$ & $\begin{array}{l}0.214^{* * *} \\
(0.048)\end{array}$ & $\begin{array}{l}0.250^{* * *} \\
(0.047)\end{array}$ \\
\hline Income_15k_20k & $\begin{array}{l}0.246^{* * *} \\
(0.069)\end{array}$ & $\begin{array}{l}0.292^{* * *} \\
(0.049)\end{array}$ & $\begin{array}{l}0.351^{* * *} \\
(0.048)\end{array}$ \\
\hline Income_20k_25k & $\begin{array}{l}0.278^{* * *} \\
(0.07)\end{array}$ & $\begin{array}{l}0.319^{* * *} \\
(0.05)\end{array}$ & $\begin{array}{l}0.421^{* * *} \\
(0.04) 8\end{array}$ \\
\hline Income_25k_30k & $\begin{array}{l}0.280 * * * \\
(0.073)\end{array}$ & $\begin{array}{l}0.378^{* * *} \\
(0.051)\end{array}$ & $\begin{array}{l}0.511^{* * *} \\
(0.049)\end{array}$ \\
\hline Income_30k_35k & $0.327^{* * *}$ & $0.392^{* * *}$ & $0.521^{* * *}$ \\
\hline
\end{tabular}

Continued on Next Page. . 
Table B.1 - Continued

\begin{tabular}{|c|c|c|c|}
\hline Variables & $\begin{array}{l}\text { Medicare Exp. } \\
(1)\end{array}$ & $\begin{array}{l}\text { Total Health Exp. } \\
(2)\end{array}$ & $\begin{array}{l}\text { Out of Pocket Exp. } \\
(3)\end{array}$ \\
\hline & $(0.075)$ & $(0.052)$ & $(0.05)$ \\
\hline \multirow[t]{2}{*}{ Income_35k_40k } & $0.385^{* * *}$ & $0.508^{* * *}$ & $0.636^{* * *}$ \\
\hline & $(0.08)$ & $(0.05) 2$ & $(0.05) 1$ \\
\hline \multirow[t]{2}{*}{ Income_40k_45k } & $0.394^{* * *}$ & $0.533^{* * *}$ & $0.655^{* * *}$ \\
\hline & $(0.083)$ & $(0.054)$ & $(0.052)$ \\
\hline \multirow[t]{2}{*}{ Income_45k_50k } & $0.283^{* *}$ & $0.514^{* * *}$ & $0.690^{* * *}$ \\
\hline & $(0.087)$ & $(0.056)$ & $(0.054)$ \\
\hline \multirow[t]{2}{*}{ Income_50plus } & $0.306^{* * *}$ & $0.577^{* * *}$ & $0.773^{* * *}$ \\
\hline & $(0.075)$ & $(0.051)$ & $(0.05)$ \\
\hline \multirow[t]{2}{*}{ No Schooling } & 0.072 & $-0.183^{*}$ & $-0.523^{* * *}$ \\
\hline & $(0.131)$ & $(0.089)$ & $(0.095)$ \\
\hline \multirow[t]{2}{*}{ Less than 8th } & -0.068 & $-0.155^{* * *}$ & $-0.208^{* * *}$ \\
\hline & -0.047 & -0.03 & -0.029 \\
\hline \multirow{2}{*}{ Some High School } & -0.048 & $-0.084^{* * *}$ & $-0.085^{* * *}$ \\
\hline & $(0.041)$ & $(0.025)$ & $(0.024)$ \\
\hline \multirow[t]{2}{*}{ Some College } & 0 & $0.062^{* *}$ & $0.088^{* * *}$ \\
\hline & $(0.035)$ & $(0.019)$ & $(0.018)$ \\
\hline \multirow[t]{2}{*}{ College } & $0.102^{*}$ & $0.137^{* * *}$ & $0.231^{* * *}$ \\
\hline & $(0.048)$ & $(0.025)$ & $(0.024)$ \\
\hline \multirow[t]{2}{*}{ Graduate School } & $0.175^{* *}$ & $0.203^{* * *}$ & $0.279^{* * *}$ \\
\hline & $(0.055)$ & $(0.027)$ & $(0.027)$ \\
\hline \multirow[t]{2}{*}{ Married } & $0.188^{*}$ & $0.184^{* * *}$ & $0.206^{* * *}$ \\
\hline & $(0.087)$ & $(0.056)$ & $(0.052)$ \\
\hline \multirow{2}{*}{ Widow } & 0.15 & $0.185^{* * *}$ & $0.220^{* * *}$ \\
\hline & $(0.087)$ & $(0.056)$ & $(0.052)$ \\
\hline \multirow[t]{2}{*}{ Divorced } & 0.052 & $0.157^{*}$ & $0.165^{* *}$ \\
\hline & $(0.097)$ & $(0.062)$ & $(0.058)$ \\
\hline \multirow[t]{2}{*}{ Separated } & -0.239 & 0.003 & -0.015 \\
\hline & $(0.168)$ & $(0.119)$ & $(0.111)$ \\
\hline \multirow[t]{2}{*}{ Black } & $-0.202^{* * *}$ & $-0.147^{* * *}$ & $-0.251^{* * *}$ \\
\hline & $(0.056)$ & $(0.034)$ & $(0.032)$ \\
\hline \multirow[t]{2}{*}{ Hispanic } & $-0.378^{* * *}$ & $-0.186^{* *}$ & $-0.582^{* * *}$ \\
\hline & $(0.099)$ & $(0.061)$ & $(0.066)$ \\
\hline \multirow[t]{2}{*}{ Other Race } & $-0.438^{* * *}$ & $-0.195^{* * *}$ & $-0.385^{* * *}$ \\
\hline & $(0.09)$ & $(0.054)$ & $(0.055)$ \\
\hline \multirow[t]{2}{*}{ Number of Kids } & -0.001 & -0.001 & -0.003 \\
\hline & $(0.007)$ & $(0.004)$ & $(0.004)$ \\
\hline \multirow[t]{2}{*}{ Good Health } & $0.400 * * *$ & $0.309^{* * *}$ & $0.224^{* * *}$ \\
\hline & $(0.026)$ & $(0.015)$ & $(0.014)$ \\
\hline Fair Health & $0.732^{* * *}$ & $0.527^{* * *}$ & $0.306^{* * *}$ \\
\hline
\end{tabular}

Continued on Next Page... 
Table B.1 - Continued

\begin{tabular}{|c|c|c|c|}
\hline Variables & $\begin{array}{l}\text { Medicare Exp. } \\
(1)\end{array}$ & $\begin{array}{l}\text { Total Health Exp. } \\
(2)\end{array}$ & $\begin{array}{l}\text { Out of Pocket Exp. } \\
(3)\end{array}$ \\
\hline & $(0.037)$ & $(0.021)$ & $(0.02)$ \\
\hline \multirow[t]{2}{*}{ Poor Health } & $1.037^{* * *}$ & $0.764^{* * *}$ & $0.334^{* * *}$ \\
\hline & $(0.062)$ & $(0.035)$ & $(0.036)$ \\
\hline \multirow[t]{2}{*}{ Eversmoke } & $0.097^{* * *}$ & $0.055^{* * *}$ & 0.026 \\
\hline & $(0.028)$ & $(0.016)$ & $(0.015)$ \\
\hline \multirow[t]{2}{*}{ Smoker } & $-0.452^{* * *}$ & $-0.386^{* * *}$ & $-0.331^{* * *}$ \\
\hline & $(0.046)$ & $(0.03)$ & $(0.028)$ \\
\hline \multirow[t]{2}{*}{ DRC35 } & -0.071 & 0.017 & $0.050^{*}$ \\
\hline & $(0.046)$ & $(0.023)$ & $(0.025)$ \\
\hline \multirow[t]{2}{*}{ DRC40 } & $-0.176^{* * *}$ & 0.008 & 0.007 \\
\hline & $(0.049)$ & $(0.025)$ & $(0.026)$ \\
\hline \multirow[t]{2}{*}{ DRC45 } & -0.09 & -0.002 & 0.012 \\
\hline & $(0.047)$ & $(0.026)$ & $(0.026)$ \\
\hline \multirow[t]{2}{*}{ DRC50 } & $-0.170^{* * *}$ & -0.014 & 0.002 \\
\hline & $(0.049)$ & $(0.026)$ & $(0.026)$ \\
\hline \multirow[t]{2}{*}{ DRC55 } & $-0.382^{* * *}$ & $-0.152^{* * *}$ & $-0.067^{*}$ \\
\hline & $(0.05)$ & $(0.03)$ & $(0.02)$ \\
\hline \multirow{2}{*}{ DRC60 } & $-0.465^{* * *}$ & $-0.232^{* * *}$ & $-0.117^{* * *}$ \\
\hline & $(0.055)$ & $(0.032)$ & $(0.031)$ \\
\hline \multirow[t]{2}{*}{ DRC65 } & $-0.599^{* * *}$ & $-0.302^{* * *}$ & $-0.147^{* * *}$ \\
\hline & $(0.079)$ & $(0.047)$ & $(0.044)$ \\
\hline \multirow[t]{2}{*}{ DRC65_FRA2 } & $-0.588^{* * *}$ & $-0.286^{* * *}$ & $-0.169^{* * *}$ \\
\hline & $(0.081)$ & $(0.047)$ & $(0.046)$ \\
\hline \multirow[t]{2}{*}{ DRC70_FRA4 } & $-0.809^{* * *}$ & $-0.360^{* * *}$ & $-0.202^{* * *}$ \\
\hline & $(0.091)$ & $(0.05)$ & $(0.047)$ \\
\hline \multirow[t]{2}{*}{ DRC70_FRA6 } & $-0.892^{* * *}$ & $-0.343^{* * *}$ & $-0.212^{* * *}$ \\
\hline & $(0.101)$ & $(0.057)$ & $(0.053)$ \\
\hline \multirow[t]{2}{*}{ DRC75_FRA8 } & $-0.823^{* * *}$ & $-0.365^{* * *}$ & $-0.207^{* * *}$ \\
\hline & $(0.106)$ & $(0.063)$ & $(0.059)$ \\
\hline \multirow[t]{2}{*}{ DRC75_FRA10 } & $-1.117^{* * *}$ & $-0.483^{* * *}$ & $-0.256^{* * *}$ \\
\hline & $(0.128)$ & $(0.071)$ & $(0.068)$ \\
\hline \multirow{2}{*}{ DRC80_FRA66 } & $-1.847^{* * *}$ & $-0.775^{* * *}$ & $-0.529^{* * *}$ \\
\hline & $(0.106)$ & $(0.067)$ & $(0.061)$ \\
\hline Year Dummy & Yes & Yes & Yes \\
\hline $\mathrm{R}^{2}$ & 0.366 & 0.268 & 0.226 \\
\hline Obs & 93909 & 93909 & 93909 \\
\hline $\begin{array}{l}\text { Note. Robust Standar } \\
* \text { Significant at } 10 \text { per } \\
\text { ** Significant at } 5 \text { per } \\
\text { *** Significant at } 1 \text { pe }\end{array}$ & ors clustered at the & vidual level are in parentl & \\
\hline
\end{tabular}


Table B.2: Medicare savings from Medicare as Secondary Payer: OLS

\begin{tabular}{|c|c|c|c|}
\hline Variables & $\begin{array}{c}\text { Medicare Exp. } \\
(1)\end{array}$ & $\begin{array}{c}\text { Total Health Exp. } \\
(2)\end{array}$ & $\begin{array}{c}\text { Out of Pocket Exp. } \\
(3)\end{array}$ \\
\hline \multirow[t]{2}{*}{ Working } & $-0.636 * * *$ & $-0.111^{* * *}$ & 0.044 \\
\hline & $(0.047)$ & $(0.024)$ & $(0.023)$ \\
\hline \multirow[t]{2}{*}{ EPCHI } & $-2.057 * * *$ & -0.01 & -0.044 \\
\hline & $(0.099)$ & $(0.049)$ & $(0.046)$ \\
\hline \multirow[t]{2}{*}{ Good Health } & $0.432^{* * *}$ & $0.316^{* * *}$ & $0.222^{* * *}$ \\
\hline & $(0.029)$ & $(0.015)$ & $(0.015)$ \\
\hline \multirow[t]{2}{*}{ Fair Health } & $0.748^{* * *}$ & $0.523^{* * *}$ & $0.278^{* * *}$ \\
\hline & $(0.042)$ & $(0.021)$ & $(0.021)$ \\
\hline \multirow[t]{2}{*}{ Poor Health } & $1.121^{* * *}$ & $0.744^{* * *}$ & $0.271^{* * *}$ \\
\hline & $(0.072)$ & $(0.036)$ & $(0.038)$ \\
\hline \multirow[t]{2}{*}{ Ever smoke } & 0.058 & $0.061^{* * *}$ & $0.032^{*}$ \\
\hline & $(0.032)$ & $(0.016)$ & $(0.016)$ \\
\hline \multirow[t]{2}{*}{ Smoker } & $-0.488^{* * *}$ & $-0.425 * * *$ & $-0.352^{* * *}$ \\
\hline & $(0.052)$ & $(0.031)$ & $(0.029)$ \\
\hline \multirow[t]{2}{*}{ Age } & $0.183^{* * *}$ & $0.108^{* * *}$ & $0.078^{* * *}$ \\
\hline & $(0.014)$ & $(0.007)$ & $(0.008)$ \\
\hline \multirow[t]{2}{*}{ Age $^{2}$} & $-0.001 * * *$ & $-0.001^{* * *}$ & $-0.000 * * *$ \\
\hline & $(0.00)$ & $(0.00)$ & $(0.00)$ \\
\hline Year Dummy & Yes & Yes & Yes \\
\hline $\mathrm{R}^{2}$ & 0.201 & 0.233 & 0.191 \\
\hline Obs & 93909 & 93909 & 93909 \\
\hline
\end{tabular}

\section{Heckman Selection Model of key results}

The table below shows the results from the Heckman selection model, and DRC dummies are used as exclusion which only appear in the first stage of the model to add non-parametric identification to the model. The results in Table C.1 are to be compared to those shown in Table 15.

\section{Work and health insurance coverage linked with delay enrollment}

Following are regression results from Probit model of delay enrollment. Marginal effects rather than the directly estimated coefficients are represented. 
Table C.1: Medicare savings from Medicare as Secondary Payer: Heckman Selection Model

\begin{tabular}{|c|c|c|c|}
\hline Variables & $\begin{array}{c}\text { Medicare Exp. } \\
(1)\end{array}$ & $\begin{array}{c}\text { Total Health Exp. } \\
(2)\end{array}$ & $\begin{array}{c}\text { Out of Pocket Exp. } \\
(3)\end{array}$ \\
\hline \multirow[t]{2}{*}{ Working } & $-0.057^{*}$ & $-0.127 * * *$ & $0.039^{* *}$ \\
\hline & $(0.023)$ & $(0.026)$ & $(0.013)$ \\
\hline \multirow[t]{2}{*}{ EPCHI } & $-0.235^{* * *}$ & 0.015 & -0.041 \\
\hline & $(0.06)$ & $(0.054)$ & $(0.027)$ \\
\hline \multirow[t]{2}{*}{ Good Health } & $0.315^{* * *}$ & $0.242^{* * *}$ & $0.158^{* * *}$ \\
\hline & $(0.015)$ & $(0.019)$ & $(0.009)$ \\
\hline \multirow[t]{2}{*}{ Fair Health } & $0.513^{* * *}$ & $0.407^{* * *}$ & $0.201^{* * *}$ \\
\hline & $(0.021)$ & $(0.026)$ & $(0.013)$ \\
\hline \multirow[t]{2}{*}{ Poor Health } & $0.899 * * *$ & $0.649 * * *$ & $0.210 * * *$ \\
\hline & $(0.034)$ & $(0.043)$ & $(0.022)$ \\
\hline \multirow[t]{2}{*}{ Ever smoke } & $0.082^{* * *}$ & $0.051^{* *}$ & $0.020^{*}$ \\
\hline & $(0.014)$ & $(0.018)$ & $(0.009)$ \\
\hline \multirow[t]{2}{*}{ Smoker } & $-0.203^{* * *}$ & $-0.167 * * *$ & $-0.144^{* * *}$ \\
\hline & $(0.023)$ & $(0.029)$ & $(0.015)$ \\
\hline \multirow[t]{2}{*}{ Age } & $0.027^{* * *}$ & $0.043^{* * *}$ & $0.036^{* * *}$ \\
\hline & $(0.006)$ & $(0.008)$ & $(0.004)$ \\
\hline \multirow[t]{2}{*}{$\operatorname{Age}^{2}$} & $-0.000 * * *$ & $-0.000 * * *$ & $-0.000 * * *$ \\
\hline & $(0.00)$ & $(0.00)$ & $(0.00)$ \\
\hline \multirow[t]{2}{*}{ Lambda } & -1.337 & -2.3473 & -0.71902 \\
\hline & $(0.1191)$ & $(0.1679)$ & $(0.0850)$ \\
\hline Year Dummy & Yes & Yes & Yes \\
\hline Obs & 93909 & 93909 & 93909 \\
\hline
\end{tabular}

Table D.1: Probit Model Regression Results of Delay Enrollment

\begin{tabular}{ll}
\hline \hline Variables & Medicare Expenditures \\
\hline Working & $\begin{array}{l}0.016^{* * *} \\
(0.003)\end{array}$ \\
Epchi & $\begin{array}{l}0.016^{* * *} \\
(0.006)\end{array}$ \\
& $0.012^{* * *}$ \\
Male & $(0.003)$ \\
& -0.003 \\
Income_5k_10k & $(0.004)$ \\
& $-0.016^{* * *}$ \\
Income_10k_15k &
\end{tabular}


Table D.1 - Continued

\begin{tabular}{|c|c|}
\hline Variables & Medicare Expenditures \\
\hline \multirow{3}{*}{ Income_15k_20k } & $(0.004)$ \\
\hline & $-0.015^{* * *}$ \\
\hline & $(0.004)$ \\
\hline \multirow[t]{2}{*}{ Income_20k_25k } & $-0.013^{* *}$ \\
\hline & $(0.004)$ \\
\hline \multirow{2}{*}{ Income_25k_30k } & $-0.011^{* * *}$ \\
\hline & $(0.005)$ \\
\hline \multirow{2}{*}{ Income_30k_35k } & $-0.014^{* * *}$ \\
\hline & $(0.005)$ \\
\hline \multirow[t]{2}{*}{ Income_35k_40k } & $-0.014^{* *}$ \\
\hline & $(0.005)$ \\
\hline \multirow[t]{2}{*}{ Income_40k_45k } & $-0.013^{* *}$ \\
\hline & $(0.005)$ \\
\hline \multirow{2}{*}{ Income_45k_50k } & -0.006 \\
\hline & $(0.005)$ \\
\hline \multirow{2}{*}{ Income_50plus } & -0.003 \\
\hline & $(0.005)$ \\
\hline \multirow{2}{*}{ No Schooling } & $0.036 * * *$ \\
\hline & $(0.006)$ \\
\hline \multirow[t]{2}{*}{ Less than 8th } & $0.009^{* *}$ \\
\hline & $(0.004)$ \\
\hline \multirow[t]{2}{*}{ Some High School } & $0.007^{*}$ \\
\hline & $(0.003)$ \\
\hline \multirow[t]{2}{*}{ Some College } & $0.009 * * *$ \\
\hline & $(0.003)$ \\
\hline \multirow[t]{2}{*}{ College } & $0.02^{* * *}$ \\
\hline & $(0.004)$ \\
\hline \multirow{2}{*}{ Graduate School } & $0.04^{* * *}$ \\
\hline & $(0.004)$ \\
\hline \multirow[t]{2}{*}{ Married } & $-0.014^{* *}$ \\
\hline & $(0.006)$ \\
\hline \multirow[t]{2}{*}{ Widow } & $-0.011^{*}$ \\
\hline & $(0.006)$ \\
\hline \multirow[t]{2}{*}{ Divorce } & -0.001 \\
\hline & $(0.006)$ \\
\hline \multirow[t]{2}{*}{ Separated } & -0.005 \\
\hline & $(0.011)$ \\
\hline \multirow[t]{2}{*}{ Black } & $0.033^{* * *}$ \\
\hline & $(0.003)$ \\
\hline \multirow[t]{2}{*}{ Hispanic } & $0.065^{* * *}$ \\
\hline & $(0.005)$ \\
\hline
\end{tabular}

Continued on Next Page... 
Table D.1 - Continued

\begin{tabular}{ll}
\hline \hline Variables & Medicare Expenditures \\
\hline Number of Kids & $0.001^{* * *}$ \\
& $(0.001)$ \\
Good Health & $0.006^{* * *}$ \\
& $(0.002)$ \\
Fair Health & 0.003 \\
& $(0.003)$ \\
Poor Health & 0.003 \\
& $(0.005)$ \\
Ever Smoke & $-0.01^{* * *}$ \\
& $(0.002)$ \\
Smoker & 0.002 \\
& $(0.003)$ \\
Age & $0.006^{* * *}$ \\
& $(0.001)$ \\
Age & $0.000^{* * *}$ \\
& $(0.000)$ \\
Year Dummies & NO \\
Observations & 93,909 \\
\hline \hline Note. Robust Standard errors clustered at the \\
individual level are in parentheses. \\
* Significant at 10 percent. \\
** Significant at 5 percent. \\
*** Significant at 1 percent. \\
\hline \hline
\end{tabular}


Table D.2: Changes to the FRA and the DRC by cohort

\begin{tabular}{|c|c|c|c|c|c|c|}
\hline Cohorts & Before 1925 & 1925-1937 & 1938-1942 & $1943-1954$ & $1955-1959$ & 1960 and after \\
\hline Changes & Not affect & Affected by DRC & \multicolumn{4}{|c|}{ Affected by DRC \& FRA } \\
\hline & $\begin{array}{l}\mathrm{DRC}=3 \% \\
\mathrm{FRA}=65\end{array}$ & $\begin{array}{l}3.5 \% \leq D R C \leq 6.5 \% \\
\mathrm{FRA}=65\end{array}$ & $\begin{array}{l}6.5 \% \leq D R C \leq 7.5 \% \\
65+1 / 6 \leq F R A<66\end{array}$ & $\begin{array}{l}\mathrm{DRC}=8 \% \\
\mathrm{FRA}=66\end{array}$ & $\begin{array}{l}\mathrm{DRC}=8 \% \\
66+1 / 6 \leq F R A<67\end{array}$ & $\begin{array}{l}\mathrm{DRC}=8 \% \\
\mathrm{FRA}=67\end{array}$ \\
\hline \multicolumn{7}{|c|}{ Address in this paper } \\
\hline
\end{tabular}

Source: Author's calculation 


\section{References}

[1] Adler, G. S. (1994). A profile of the medicare current beneficiary survey. Health Care Financing Review, 15(4):153-163.

[2] Aísa, R., Pueyo, F., and Sanso, M. (2012). Life expectancy and labor supply of the elderly. Journal of Population Economics, 25(2):545-568.

[3] Albouy, V., Davezies, L., and Debrand, T. (2010). Health expenditure models: A comparison using panel data. Economic Modeling, 27:791-803.

[4] Atherly, A. (2001). Supplemental insurance: Medicare's accidental stepchild. Medical Care Research and Review, 58(2):131-161.

[5] Benítez-Silva, H., Dwyer, D. S., Sanderson, W., and Heiland, F. (2009). Retirement and social security reform expectations: A solution to the new early retirement puzzle. Manuscript.

[6] Benítez-Silva, H. and Yin, N. (2009). An empirical study of the effects of social security reforms on benefit claiming behavior and receipt using public-use administrative microdata. Social Security Bulletin, 69(2).

[7] Blau, D. M. and Goodstein, R. (2007). What explains trends in labor force participation of older men in the united states? IZA Discussion Papers, (2991).

[8] Blau, D. M. and Goodstein, R. M. (2010). Can social security explain trends in labor force participation of older men in the united states? Journal of Human Resources, 45(2):328-363.

[9] Bound, J., Levy, H., and Nicholas, L. H. (2013). Social security benefit claiming and medicare utilization. Working paper, Michigan Retirement Research Center.

[10] Bound, J., Stinebrickner, T., and Waidmann, T. (2010). Health, economic resources and the work decisions of older men. Journal of Econometrics, 156(1):106 -129 .

[11] Cartwright, W. S., Hu, T., , and Huang, L. (1992). Impact of varying medigap insurance coverage on the use of medical services of the elderly. Applied Economics, 24.

[12] CBO (2005). High-cost medicare beneficiaries. Washington, DC: Congressional Budget Office.

[13] CBO (2011). March 2011 medicare baseline. Washington, DC: Congressional Budget Office.

[14] CBO (2014). The budget and economic outlook: 2014 to 2024. Washington, DC: Congressional Budget Office. 
[15] Chaze, J.-P. (2005). Assessing household health expenditure with box-cox censoring models. Health Economics, 14:893-907.

[16] Christensen, S. and Shinogle, J. (1997). Effects of supplemental coverage on use of services by medicare enrollees. Health Care Financing Review, 19(1):5-18.

[17] CMS. Medicare general information, eligibility, and entitlement. Baltimore: U.S. Dept. Health and Human Services.

[18] CMS. Medicare managed care manual. Baltimore: U.S. Dept. Health and Human Services.

[19] CMS (2009). Annual release of part d national average bid amount and other part c and d bid information. Baltimore: U.S. Dept. Health and Human Services.

[20] CMS (2015). Choosing a medigap policy: A guide to health insurance for people with medicare. Baltimore: U.S. Dept. Health and Human Services.

[21] DiCecio, R., Engemann, K. M., Owyang, M. T., and Wheeler, C. H. (2008). Changing trends in the labor force: a survey. Federal Reserve Bank of St. Louis Review, pages 47-62.

[22] Dow, W. H. and Norton, E. C. (2003). Choosing between and interpreting the heckit and two-part models for corner solutions. Health Services and Outcomes Research Methodology, 4:5-18.

[23] Duggan, M., Singleton, P., and Song, J. (2007). Aching to retire? the rise in the full retirement age and its impact on the social security disability rolls. Journal of Public Economics, 91(7-8):1327-1350.

[24] Ettner, S. L. (1997). Adverse selection and the purchase of medigap insurance by the elderly. Journal of Health Economics, 16(5):543-562.

[25] Fang, H. and Gavazza, A. (2011). Dynamic inefficiencies in an employmentbased health insurance system: Theory and evidence. American Economic Review, 101(7):3047-77.

[26] Fang, H., Keane, M. P., and Silverman, D. (2008). Sources of Advantageous Selection: Evidence from the Medigap Insurance Market. Journal of Political Economy, 116(2):303-350.

[27] French, E. (2005). The effects of health, wealth, and wages on labor supply and retirement behavior. The Review of Economic Studies, 72(3):395-427.

[28] French, E. and Jones, J. B. (2004). On the distribution and dynamics of health care costs. Journal of Applied Econometrics, 19(6):705-721.

[29] Griswold, M., Parmigiani, G., Potosky, A., and Lipscomb, J. (2004). Analyzing health care costs: A comparison of statistical methods motivated by medicare colorectal cancer charges. Biostatistics, 1:1-23. 
[30] Gustman, A. L. and Steinmeier, T. (2009). How changes in social security affect recent retirement trends. Research on Aging, 31(2):261-290.

[31] Gustman, A. L. and Steinmeier, T. L. (1985). The 1983 social security reforms and labor supply adjustments of older individuals in the long run. Journal of Labor Economics, 3(2):237-53.

[32] Gustman, A. L. and Steinmeier, T. L. (1991). Changing the social security rules for work after age 65. Industrial and Labor Relations Review, 44(4):733-745.

[33] Hill, J., Brown, R., Chu, D., and Bergeron, J. (1992). The impact of the medicare risk program on the use of services and costs to medicare. Mathematica Policy Research.

[34] Hurd, M. D. and McGarry, K. (1997). Medical insurance and the use of health care services by the elderly. Journal of Health Economics, 16(2):129-154.

[35] Kaiser, F. F. (2013). Medigap: Spotlight on enrollment, premiums and trends.

[36] Kaiser, F. F. (2015). Medicare advantage 2015 data spotlight: Overview of plan changes.

[37] Keane, M. and Stavrunova, O. (2011). A smooth mixture of tobits model for healthcare expenditure. Healt Economics, 20:1126-1153.

[38] Khandker, R. K. and McCormack, L. A. (1999). Medicare spending by beneficiaries with various types of supplemental insurance. Medical Care Research and Review, 56(2):137-55.

[39] Link, C. R., Long, S. H., and Settle, R. F. (1980). Cost sharing, supplementary insurance, and health services utilization among the medicare elderly. Health Care Financing Review, 2(2):25-31.

[40] Lubitz, J., Beebe, J., and Baker, C. (1995). Longevity and medicare expenditures. New England Journal of Medicine, 332(15):999-1003.

[41] Mastrobuoni, G. (2009). Labor supply effects of the recent social security benefit cuts: Empirical estimates using cohort discontinuities. Journal of Public Economics, 93(11-12):1224-1233.

[42] McCall, N., Rice, T., Boismier, J., and West, R. (1991). Private health insurance and medical care utilization: Evidence from the medicare population. Inquiry, 28:276-87.

[43] Miller, T. (2001). Increasing longevity and medicare expenditures. Demography, $38(2): 215-226$.

[44] Mitchell, O. S. and Phillips, J. W. R. (2000). Retirement responses to early social security benefit reductions. Working paper, Michigan Retirement Research Center. 
[45] Munnell, A. H. (2003). The declining role of social security. Just the Facts On Retirement Issues, (6).

[46] Munnell, A. H. and Sass, S. A. (2007). The labor supply of older americans. Working Papers, Center for Retirement Research at Boston College, (2007-12).

[47] Pingle, J. F. (2006). Social security's delayed retirement credit and the social security's delayed retirement credit and the labor supply of older men. Working paper, Board of Governors of the Federal Reserve.

[48] Schirle, T. (2008). Why have the labor force participation rates of older men increased since the mid-1990s? Journal of Labor Economics, 26(4):549-594.

[49] Song, J. G. and Manchester, J. (2007). Have people delayed claiming retirement benefits? responses to changes in social security rules. Social Security Bulletin, $67(2): 1-15$.

[50] SSA (2011). Medicare program description and legislative history. Annual Statistical Supplement.

[51] Wennberg, J. E., Fisher, E. S., and Skinner, J. S. (2002). Geography and the debate over medicare reform. Health Aff (Millwood).

[52] Zuckerman, S., Waidmann, T., Berenson, R., and Hadley, J. (2010). Clarifying sources of geographic differences in medicare spending. The New England Journal of Medicine, 363:54-62. 